\title{
Double-difference relocation of earthquakes in central-western China, 1992-1999
}

\author{
Z.X. Yang ${ }^{1, *}$, F. Waldhauser ${ }^{2}$, Y.T. Chen ${ }^{1}$ \& P.G. Richards ${ }^{2}$ \\ ${ }^{1}$ Institute of Geophysics, China Seismological Bureau, Beijing 100081, China; ${ }^{2}$ Lamont-Doherty Earth \\ Observatory, Columbia University, NY 10964, USA \\ *Author for correspondence: e-mail: zhixian@public.bta.net.cn
}

Received 8 October 2004; accepted in revised form 16 March 2005

Key words: central-western China, double-difference earthquake location, earthquake relocation, seismogenic layer

\begin{abstract}
The double-difference earthquake location algorithm was applied to the relocation of 10,057 earthquakes that occurred in central-western China $\left(21^{\circ} \mathrm{N}\right.$ to $36^{\circ} \mathrm{N}, 98^{\circ} \mathrm{E}$ to $\left.111^{\circ} \mathrm{E}\right)$ during the period from 1992 to 1999 . In total, 79,706 readings for $\mathrm{P}$ waves and 72,169 readings for $\mathrm{S}$ waves were used in the relocation. The relocated seismicity (6,496 earthquakes) images fault structures at seismogenic depths that are in close correlation with the tectonic structure of major fault systems expressed at the surface. The new focal depths confirm that most earthquakes $(91 \%)$ in this region occur at depths less than $20 \mathrm{~km}$.
\end{abstract}

\section{Introduction}

Our study area is the central-western China, extending roughly from $21^{\circ} \mathrm{N}$ to $36^{\circ} \mathrm{N}$ and $98^{\circ} \mathrm{E}$ to $111^{\circ} \mathrm{E}$ (Figure 1). As the tectonic map indicates (see Figure 1a), the Chinese mainland and its surrounding area are located in the southeastern part of the Eurasian plate bounded by the Indian, the Philippine Sea and the Pacific plates. The region is characterized by strong northeastward motion of the Indian plate with respect to southwestern China, by the westward subduction of the Pacific plate beneath eastern China, and by the northwestward impact of the Philippine Sea plate (Molnar and Tapponier, 1975; Teng et al., 1979; Zhou et al., 1998; Wang et al., 2001; Qin et al., 2002). The study area can be broadly divided into a western part and an eastern part along $105^{\circ} \mathrm{E}$ longitude (see Figure $1 \mathrm{~b}$ ). The western part has a complicated tectonic structure and is characterized by a high rate of seismic release, while the eastern part has a lower level of seismic activity (Chen et al., 1992; Min, 1995; Wang et al., 1999). In the western part, several major active faults, including the Honghe (Red River) Fault (F1 in Figure 1b), the Xiaojiang Fault (F2), the Xianshuihe Fault (F3) and the
Jinshajiang Fault (F4), and seismic belts, including the Lijiang seismic belt (R3) and the Yongsheng-NinglangMuli-Jiulong seismic belt (R4), outline a diamondshaped tectonic block, first noted and named as the Sichuan-Yunnan rhombic tectonic block by Kan et al. (1977). To the northeast of this structure is the $470 \mathrm{~km}$ long, NE striking Longmenshan Fault (F5), and to the southwest the NNW striking Tengchong-Longling (R1) and Lancang-Gengma seismic belts (R2). Previous studies (Kan et al., 1977; Li, 1993; Wen, 1998) indicate that some of the larger earthquakes of the region have occurred along these major fault systems, both historically and recently (Figure $1 \mathrm{~b}$, Table A1). In contrast, to the east of $105^{\circ} \mathrm{E}$ longitude the seismicity is low, in particular to the south of $34^{\circ} \mathrm{N}$ where no major earthquake has been documented and current micro-seismicity is low. An exception is the area of increased seismicity around the Baise-Hepu Fault (F8). The northeastern part is dominated by the E-W striking Northern Qinling Fault (F6 in Figure 1b) and the NE striking Weihe fault (F7), along which several larger earthquakes occurred historically.

The large earthquakes with $M \geq 7$ shown in Figure $1 \mathrm{~b}$ have taken place mainly along active faults 
expressed at the surface, and have in fact contributed, in many cases, to their formation (Ma, 1987, 1989; Ding, 1991, 1996; Deng et al., 1994). But the relationship between the thousands of microearthquakes recorded with modern instruments (Figure 2) and the active faults and associated large earthquakes has never previously been studied in detail in this area - a fact which has motivated our work. The instrumental seismicity is diffuse, and in previous studies has not indicated a clear association to the faults at the surface, or to the large events that occurred along these structures. A main problem in studying the temporal and spatial

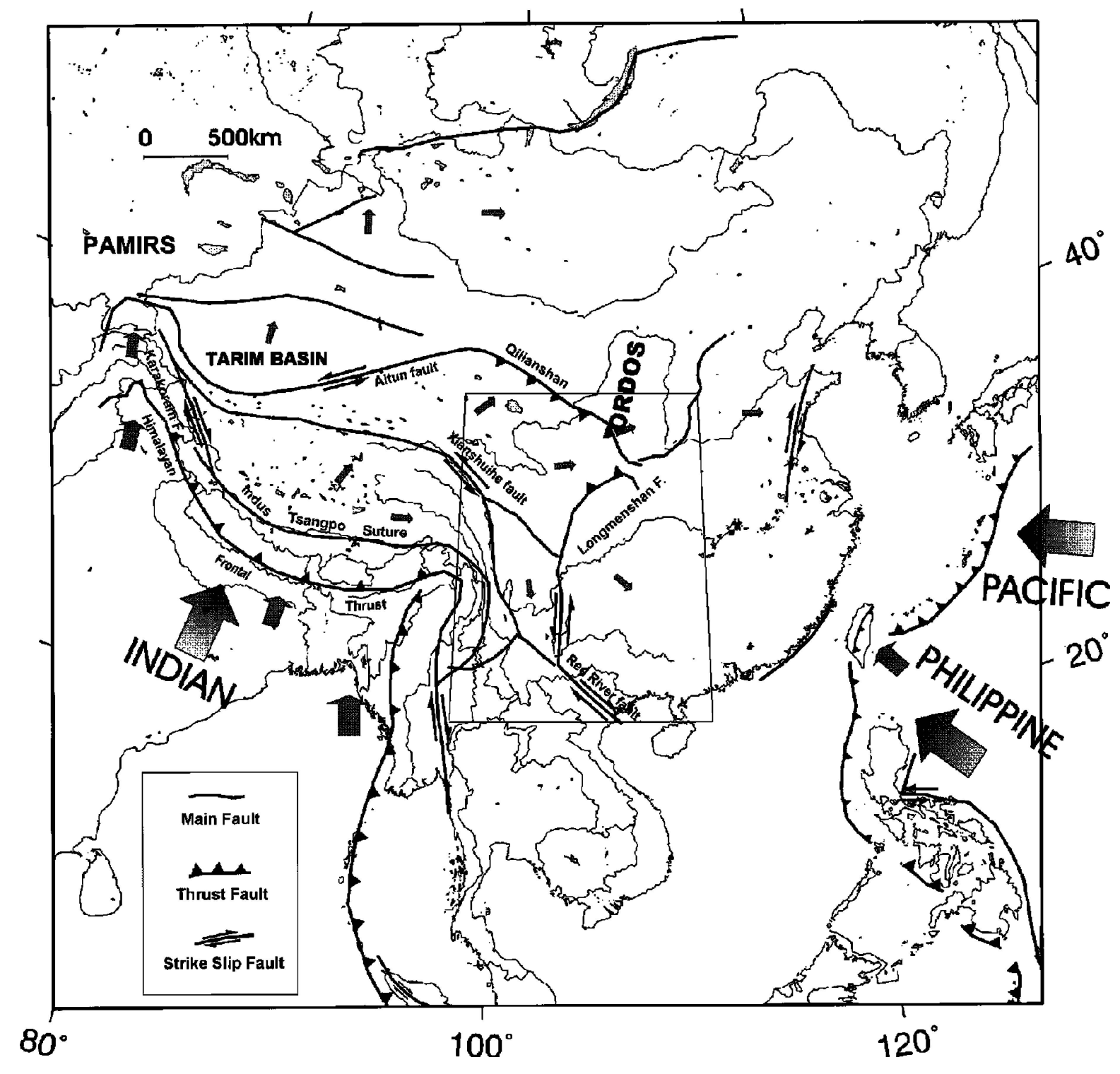

(a)

Figure 1. Setting of active tectonic structure (a) and seismicity of major earthquakes of $M \geq 7$ from 780 B. C. to April 2003 in central-western China (b). Thick black lines represent surface traces of active faults (Deng et al., 1994), thin lines represent provincial boundaries; gray and black circles indicate major events with $M \geq 7$ before 1911 (Min, 1995) and after 1911 (Wang et al., 1999), respectively; open circles represent some events of $6 \leq M<7$ with available fault plane solutions. The identification number, above each circle and beach ball representation of lower hemisphere projection of focal mechanism, refers to the earthquake numeral given in Table A1 and cited in the text. The thick black arrow represents the NNW to SSE motion of the Sichuan-Yunnan diamond-shaped tectonic block. 


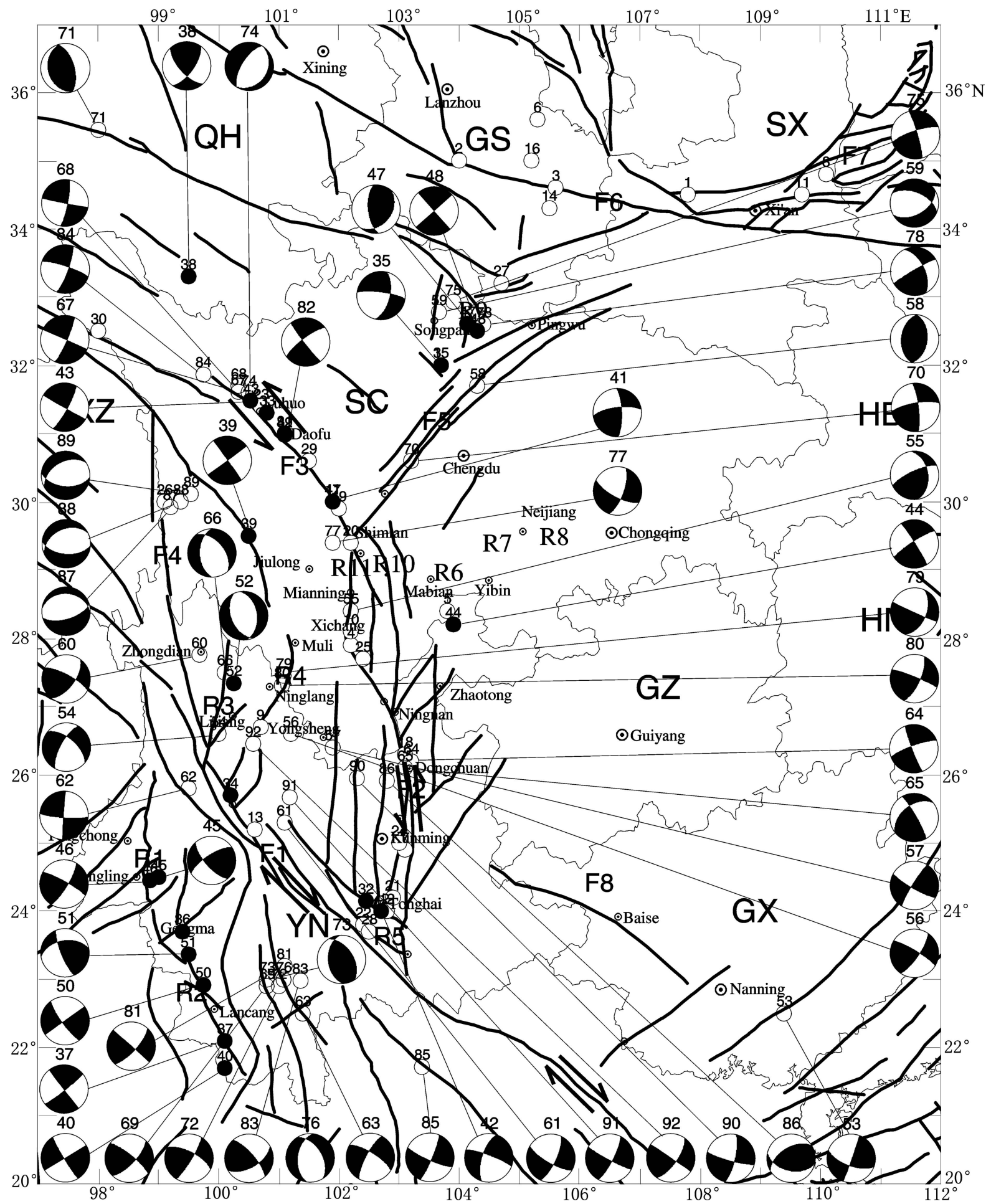

(b) 


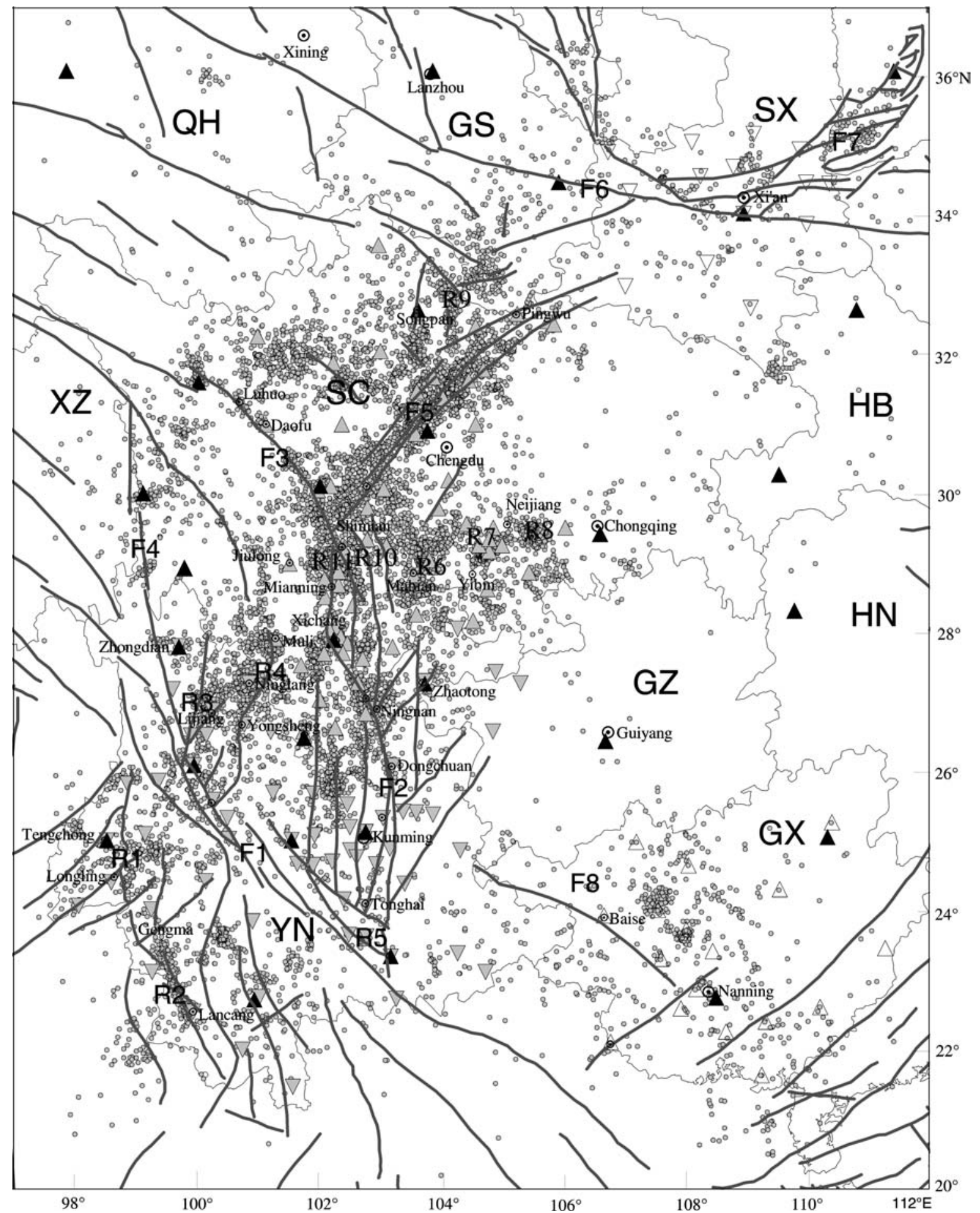

Figure 2. Epicentral distribution of the all 15,092 routinely located earthquakes (gray circles) for the period from 1992 to 1999. Thick black lines represent surface traces of active faults, thin lines represent provincial boundaries. Gray triangles represent stations of Sichuan (SC) Province Seismic Network, gray upside-down triangles represent stations of the Yunnan (YN) Province Seismic Network (YNSN), open upside-down triangles represent stations of the Shaanxi (SX) Province Seismic Network, open triangles represent stations of the Guangxi (GX) Province Seismic Network and black triangles represent stations of the China National Seismic Network (CNSN). 
distribution of the seismicity is the large error associated with published locations of these earthquakes. These errors are mainly due to oversimplified velocity models used in the routine location process, errors in arrival time readings, and lack of suitable station coverage. The latter source of error is especially common for events near the boundaries of individual provinces, resulting in large azimuthal gaps in the station distribution, unless as in this study, the data from different networks are combined.

The study area includes all of four provinces, namely Sichuan (hereafter referred to as SC), Yunnan (YN), Guizhou (GZ) and Guangxi (GX); and parts of at least six additional provinces, namely Qinghai $(\mathrm{QH})$, Gansu (GS), Shaanxi (SX), Hubei (HB), Hunan (HN) and Xizhang (XZ).

In this study we combine all the available phases from the four provincial (SC, YN, SX and GX) seismic networks and the China National Seismic Network (CNSN). We relocate the events using the doubledifference algorithm (DD algorithm) of Waldhauser and Ellsworth (2000). The relocated seismicity distribution is investigated in terms of its relationship to faults mapped at the surface and the location of large recent and historical earthquakes.

\section{Seismotectonic setting}

While the Honghe Fault (F1 in Figure 1b), marking the southwestern end of the diamond-shaped tectonic block, is a right-lateral strike-slip fault, both the Xianshuihe Fault (F3) at the northern end and the Xiaojiang Fault (F2) at the eastern end are left-lateral strike-slip faults. Focal mechanisms (Kan et al., 1977; Xu et al., 1989) of earthquakes bounding the tectonic block (Figure 1b) reveal a NNE horizontal maximum compressive stress for the region, which suggests a relative movement of the block to the SSE (Kan et al., 1977). Along the Honghe Fault, the rate of slip since the Quaternary is about 4-6 mm/yr on the northern segment, and $7-9 \mathrm{~mm} / \mathrm{yr}$ on the southern segment of the fault (Guo et al., 1984; Su and Qin, 2001). Strong earthquakes have occurred frequently along the Honghe Fault in historic times. Among the most important historical events are the 1925 Dali earthquake of $M_{\mathrm{S}} 7.0$ (No. 34 in Figure 1b and Table A1 - hereafter a numeral cited in the text refers to the earthquake identification number, above each circle and beach ball representation of lower hemisphere projection of focal mechanism in Figure $1 \mathrm{~b}$ and Table A1), and the instrumental 1970
Tonghai earthquake of $M_{\mathrm{S}} 7.8$ (No. 42) that ruptured the northwestern and southeastern parts of the Honghe fault, respectively. Along the Xiaojiang Fault (F2), the rate of slip since the Quaternary is about $6.4-8.8 \mathrm{~mm} / \mathrm{yr}$ (Su and Qin, 2001; Li, 1993) and several strong earthquakes, including the 1833 Songming earthquake of $M 8$ (No. 24) and the 1966 Dongchuan earthquake of $M_{\mathrm{S}} 6.5$ (No. 64) have occurred. Along the Xianshuihe Fault (F3), the annual rate of slip since the Quaternary is about $8-15 \mathrm{~mm} / \mathrm{yr}$ (Su and Qin, 2001). Historically, a series of large earthquakes have taken place along this fault, in particular on the Luhuo-Daofu segment (Figure 1b) as follows: the 1816 earthquake of $M 7.5$ (No. 23), the 1893 earthquake of $M 7$ (No. 29), the 1904 earthquake of $M 7$ (No. 31), the 1923 earthquake of magnitude $M 7.3$ (No. 33), the 1973 earthquake of $M_{\mathrm{S}} 7.6$ (No. 43), and the 1981 earthquake of $M_{\mathrm{S}} 7.0$ (No. 49).

Several structures with a high rate of seismic activity exist outside and inside the Sichuan-Yunnan diamond-shaped tectonic block. The Longmenshan Fault (F5) northeast of the block frequently ruptures in small to moderate size earthquakes, but no earthquakes with $M \geq 7$ have been documented along this fault. As shown in Figure 2, about 2,400 events with magnitudes between 1.0 and 5.0 occurred on or near the Longmenshan Fault (F5) during 1992 to 1999. Some earthquakes with magnitudes around 6 occurred here historically, such as the 1657 Wenchuan earthquake of $M 6.5$ (epicentral location: $31.3^{\circ} \mathrm{N}, 103.5^{\circ} \mathrm{E}$ ) and the 1970 Dayi earthquake of $M_{\mathrm{S}} 6.2($ No. 70$)(\mathrm{Gu}$, 1983; Xie and Cai, 1983-1987). Along the TengchongLongling seismic belt (R1) in the southwestern corner of the study area, two large earthquakes with $M_{\mathrm{S}} 7.3$ and $M_{\mathrm{S}} 7.4$ (Nos. 45 and 46 in Figure $1 \mathrm{~b}$ and Table A1) occurred within about 100 min on May 29, 1976. Similarly, two large earthquakes with $M_{\mathrm{S}} 7.4$ and $M_{\mathrm{S}}$ 7.2 (Nos. 50 and 51) occurred within about $12 \mathrm{~min}$ on the Lancang-Gengma seismic belt (R2) on November 6, 1988. The two parallel running, N-S striking Lijiang (R3) and Yongsheng-Ninglang seismic belts (R4) within the Sichuan-Yunnan diamond-shaped tectonic block ruptured in a $M_{\mathrm{S}} 7.0$ event on February 3, 1996 (No. 52), and a historical event of $M 7.8$ in 1515 (No. 9), respectively. Most recently, on October 27, 2001, a moderate size earthquake with $M_{\mathrm{S}} 6.0$ (No. 92) occurred in the Yongsheng-Ninglang-Muli-Jiulong seismic belt (R4). The Tonghai-Shiping seismic belt (R5) at the southeastern corner of the diamond-shaped block features a series of strong earthquakes (Nos. 12, 21, 22, 28,32 and 42 ) both historically and recently, including 
the 1970 Tonghai earthquake of $M_{\mathrm{S}} 7.8$ (No. 42) on the Honghe Fault (F1) described above. It can be said that the western part of this study area is one with complex tectonic structures and a very high level of seismicity.

In contrast to the western part of the study area, the eastern part shows a much lower level of seismic activity. The large earthquakes to the north of the Northern Qinling Fault (F6) are mainly historical events (Nos. 1,8 and 11), which occurred along the Weihe Fault (F7). In the southern part, no large events have been documented, but a relatively large number of small to moderate size earthquakes have occurred over the past years (Figure 2). These events are located around the Baise-Hepu Fault (F8), but do not show us very clear association to the major fault system.

\section{Earthquake relocation}

In the study area a total of 15,092 earthquakes were routinely located for the period from 1992 to 1999 in central-western China (Figure 2) using data from four provincial seismic networks in the Sichuan, Yunnan, Shaanxi, and Guangxi provinces, plus the CNSN. Among these earthquakes, 10,057 events were recorded by at least 4 stations. We used P- and S-phase picks from the 10,057 earthquakes recorded at 193 stations and reported in bulletins of the above-mentioned five seismic networks. A total of 79,706 P-phase picks and 72,169 S-phase picks were used from the 10,057 earthquakes. The individual seismic networks only reported focal depths for 4,876 events ( $49 \%$ of the 10,057 events). If we exclude the events whose depths are not reported, then the mean depth is $14.3 \mathrm{~km}$, with depths ranging from $1 \mathrm{~km}$ to $53 \mathrm{~km}$. These network locations are determined on a routine basis, adopting oversimplified propagation models for differrent provincial seismic networks.

Before relocation the epicenter locations of the resulting catalog located by the above-mentioned five seismic networks indicate a diffuse distribution across the study area (Figure 2).

The relative event location procedure is used to increase the precision of hypocenter locations. Relative earthquake location methods depend on the seismic wave velocity structure in the source region rather than on the structure along the entire ray path from a particular hypocenter to a station as in absolute location procedures. In the master event technique (Fukao, 1972; Fitch, 1975; Chung, 1976; Yang et al., 1999, 2002), travel time differences are taken between an as- signed (master) event and its neighboring events, improving locations for clusters of events that have dimensions smaller than the scale-length of the velocity heterogeneities between sources and receivers. Got et al. (1994) extended this idea to include travel time differences not only relative to one event, but between all neighboring events. They used differential times measured by cross-correlation to solve for interevent distances relative to the centroid of a cluster of events. This approach limits the spatial scale of possible applications. Based on these earlier studies Waldhauser and Ellsworth (2000) have designed a double-difference algorithm to optimally relocate seismic events across large areas, using routinely picked arrival times of standard phases, high precision cross-correlation measurements (if available), or a combination of phase picks and cross-correlation measurements.

The fundamental equation of the double-difference algorithm relates the differences between the observed and predicted phase travel times for pairs of earthquakes observed at common stations to changes in the vector connecting their hypocenters. In this approach, hundreds or thousands of earthquakes can be 'linked' together through a chain of near neighbors. By choosing only relative phase travel times for events that are close together (i.e., closer than the scale-length of the surrounding velocity heterogeneity), wave paths outside the source region are similar enough that common model travel time errors are canceled for each pair of events. It is then possible to obtain high-resolution hypocenter locations over large areas without the use of station corrections.

We used the program hypoDD (Waldhauser, 2001) that implements the DD algorithm to refine the available event locations. We searched the phase pick data for an appropriate network of phase travel time differences that efficiently links together as many events as possible through a chain of neighboring events. In this process event pairs with interevent distances up to $20 \mathrm{~km}$ were considered, to account for possible large mislocations in the initial locations. The P-phase travel time differences are initially weighted 1, S-phases 0.5 . During the iterative least-squares procedure, the data is reweighted after each iteration depending on the distances between the events, and depending on the residuals between the observed and the calculated travel time differences. The conjugate gradient method is used to solve the large system of normal equations. Travel time differences are predicted using a 1-D layered velocity model used for relocations in this study (Table 1). The 1-D layered seismic wave velocity model used for 
Table 1. Velocity model used for relocations in this study

\begin{tabular}{lll}
\hline Layer & $\begin{array}{l}\text { Depth to top } \\
\text { of layer }(\mathrm{km})\end{array}$ & $\begin{array}{l}\text { P-wave } \\
\text { velocity }(\mathrm{km} / \mathrm{s})\end{array}$ \\
\hline 1 & 0.0 & 5.00 \\
2 & 7.5 & 5.48 \\
3 & 16.0 & 5.93 \\
4 & 20.0 & 6.43 \\
5 & 30.0 & 6.60 \\
6 & 50.0 & 8.30 \\
\hline
\end{tabular}

predicting the travel time differences is based on previous studies of seismic wave velocity structure for the study region (Zhao et al., 1987, 1997; Yang et al., 2004). This model is appropriate for the purpose for predicting the travel time differences because the DD algorithm is a relative earthquake location method which is much less dependent on the models, compared with "absolute" methods (Waldhauser and Ellsworth, 2000). The search for continuous areas of seismicity with well linked events resulted in more than 200 clusters, including a total of 8,208 events ( $82 \%$ of the total amount of 10,057 events in the catalogue). $18 \%$ of the total number of events were not recorded by enough stations that are common to at least one neighboring event within $20 \mathrm{~km}$ distance. Most of the clustered events occur in isolated areas and include only a few events. In total, the hypocentral parameters of 6,496 relocated events were obtained. The six largest clusters have between 85 and 4,041 events, including a total of 5,827 events (Table 2). After relocation, the root-mean-square (RMS) residuals were reduced significantly. As an example, Figure 3 shows the reduction of RMS residuals after iteration for each of the six largest clusters. For the largest cluster, for example, the RMS residual is reduced from $1.83 \mathrm{~s}$

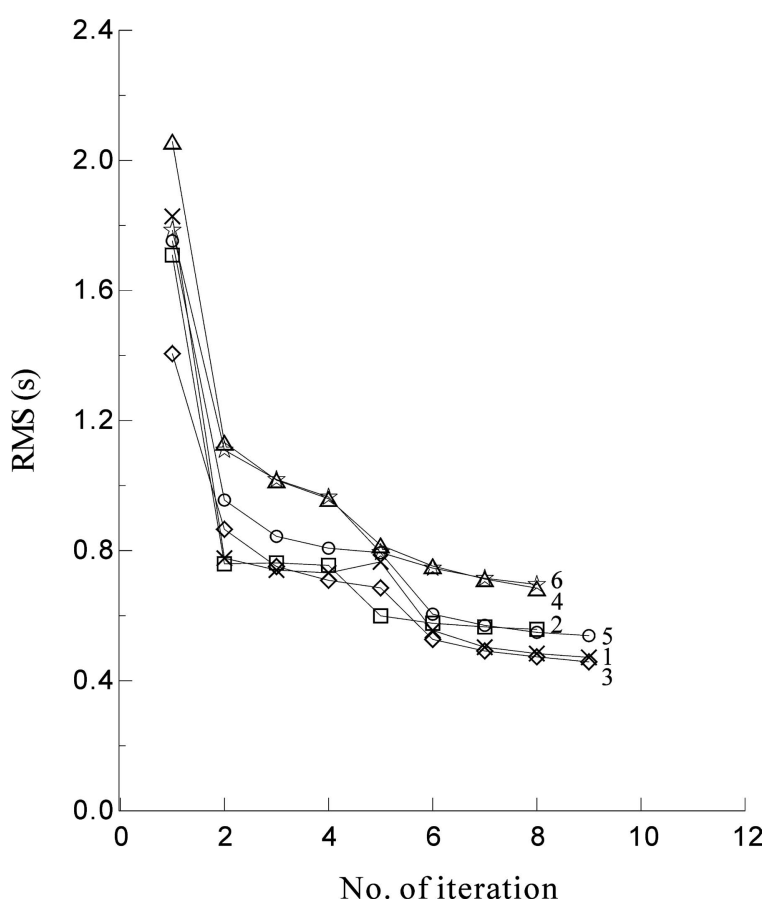

Figure 3. RMS residuals as a function of iteration steps, displayed for each of the six largest clusters. RMS residuals for cluster 1 to cluster 6 are shown with cross (line 1), open square (line 2), open diamond (line 3), open triangle (line 4), open circle (line 5) and open star (line 6)

to $0.47 \mathrm{~s}$. Similar results are obtained for other clusters (Table 2). The average RMS residual of the six largest clusters is reduced from the original $1.76 \mathrm{~s}$ to the final $0.57 \mathrm{~s}$ (Table 1, Figure 3). The relative uncertainties of relocation for the six largest clusters, on average, are $1.2 \mathrm{~km}, 1.2 \mathrm{~km}$ and $1.4 \mathrm{~km}$ for E-W, N-S and vertical directions, respectively (Table 2).

Further information on the uncertainties in relative location are given in Table 3, and the mean of

Table 2. Reduced residuals and uncertainties of relocation for the six largest clusters

\begin{tabular}{|c|c|c|c|c|c|c|c|c|c|c|}
\hline \multirow[b]{2}{*}{ Cluster } & \multicolumn{2}{|c|}{ Event number } & \multicolumn{3}{|c|}{ Centroid } & \multicolumn{2}{|c|}{ RMS residuals (s) } & \multicolumn{3}{|c|}{ Uncertainty of relocation $(\mathrm{m})$} \\
\hline & Initial & Relocated & Lat. $\left({ }^{\circ} \mathrm{N}\right)$ & Long. $\left({ }^{\circ} \mathrm{E}\right)$ & Depth $(\mathrm{km})$ & Initial & Relocated & E-W & $\mathrm{N}-\mathrm{S}$ & Vertical \\
\hline 1 & 4,041 & 3,130 & 30.737 & 103.315 & 15.5 & 1.83 & 0.47 & 856.8 & 869.4 & $1,210.2$ \\
\hline 2 & 1,010 & 763 & 29.346 & 105.231 & 8.7 & 1.71 & 0.56 & $1,164.4$ & $1,527.7$ & $1,600.6$ \\
\hline 3 & 241 & 209 & 27.080 & 102.794 & 10.5 & 1.41 & 0.46 & 933.4 & 809.0 & $1,094.0$ \\
\hline 4 & 228 & 157 & 27.205 & 100.915 & 6.0 & 2.06 & 0.68 & $1,678.0$ & $1,627.7$ & $1,795.4$ \\
\hline 5 & 222 & 179 & 25.885 & 102.214 & 10.0 & 1.75 & 0.54 & $1,321.0$ & $1,168.1$ & $1,432.4$ \\
\hline 6 & 85 & 76 & 28.495 & 101.085 & 8.2 & 1.79 & 0.70 & $1,220.7$ & $1,437.5$ & $1,480.9$ \\
\hline Average & & & & & & 1.76 & 0.57 & $1,195.7$ & $1,239.9$ & $1,435.6$ \\
\hline
\end{tabular}


Table 3. Uncertainties of the 6,496 relocated events

\begin{tabular}{|c|c|c|c|c|c|c|c|c|}
\hline & \multicolumn{2}{|c|}{$0 \leq$ Uncertainty $\leq 2 \mathrm{~km}$} & \multicolumn{2}{|c|}{$0 \leq$ Uncertainty $\leq 3 \mathrm{~km}$} & \multicolumn{2}{|c|}{$0 \leq$ Uncertainty $\leq 5 \mathrm{~km}$} & \multicolumn{2}{|c|}{ Uncertainty $>5 \mathrm{~km}$} \\
\hline & Event number & $\%$ & Event number & $\%$ & Event number & $\%$ & Event number & $\%$ \\
\hline E-W & 5,397 & 83 & 5,850 & 91 & 6,294 & 97 & 202 & 3 \\
\hline $\mathrm{N}-\mathrm{S}$ & 5,309 & 82 & 5,851 & 90 & 6,277 & 97 & 219 & 3 \\
\hline Vertical & 4,904 & 76 & 5,732 & 88 & 6,259 & 96 & 237 & 4 \\
\hline
\end{tabular}

the relative uncertainties of all the relocated events is $1.4 \mathrm{~km}, 1.5 \mathrm{~km}$ and $1.7 \mathrm{~km}$ for E-W, N-S and vertical directions, respectively. These errors are derived from bootstrapping the unweighted residual vector. They are compatible with the fact that the distribution of seismic stations in the study area is sparse, with spacing of about $50 \mathrm{~km}$ to $100 \mathrm{~km}$.

\section{Relocation results}

Figure 4 shows the epicentral distribution of all the 6,496 relocated events (open circles). A much sharper image of the seismicity is obtained, compared to the initial locations of the all 6,496 events before relocation (gray circles in Figure 4) as well as that of the 15,092 routinely located events (gray circles in Figure 2). A comparison between the epicentral distributions of earthquakes before and after relocation indicates that when analysing seismicity, based on the data before relocation, one must use caution. In general, seismicity pattern represented by the epicentral distribution before relocation is diffuse and very likely biased, and hinders understanding the links between microseismicity and active tectonics in the study area, especially when using data recorded by the analog-recording seismic networks. We note that in the final results of this study, almost all the aftershock sequences are excluded in the relocation. The only exception is the aftershock sequence of the 1996 Lijiang, Yunnan, earthquake of $M_{\mathrm{S}} 7.0$, in which about 120 aftershocks are included in the relocation. The relocated seismicity correlates strongly with tectonic activity expressed and mapped at the surface, and with the location and focal mechanism of large historic and recent earthquakes. Only about 630 events ( $10 \%$ of the total) occurs off - recognized faults. In particular, the correlation of the relocated seismicity correlates with the major seismic belts. Below, we discuss in some detail the following seismic belts: LancangGengma (R2), Lijiang (R3) and Yongsheng-NinglangMuli-Jiulong (R4); Longmenshan (F5), Mabian (R6),
Yibin (R7), and Neijiang (R8); and Songpan (R9), Shimian (R10) and Mianning (R11).

The focal depth of all events is relocated refered to the hypocentroid of the 274 routinely well-located events. These routinely well-located events are chosen by the criterion that at least one seismic station is located within the epicentral distance of travel time difference of P- and S-waves equal to or less than $2.0 \mathrm{~s}$. Thus the resultant focal depth is independent of the zero depth innitial value of the events without reported focal depths. In the same sense as the 274 well-located events, the relocated focal depth is regarded as "absolute" focal depth. Figure 5a shows relocated focal depths and uncertainties of all the 6,496 relocated earthquakes projected along a N-S profile. Most earthquakes (91\%) in central-western China are situated at a depth interval between 0 and $20 \mathrm{~km}$. This can also be seen in a histogram of the focal depths of all the relocated earthquakes (Figure 5b). The mean depth for all relocated events is about $11.7 \mathrm{~km}$, significantly shallower than the mean depth reported in previous studies (Ma and Xue, 1983; Zhang et al., 2002).

Previous studies indicated that focal depths of the earthquakes in central-western China are predominantly distributed between $10 \mathrm{~km}$ and $25 \mathrm{~km}$ (Ma and Xue, 1983). Zhang et al. (2002) made a statistical analysis of routinely determined focal depths of 31,282 earthquakes with $M_{\mathrm{L}} \geq 2.0$ which occurred in western China. In their study, the reported depth uncertainties of $60 \%$ of these earthquakes are less than $4 \mathrm{~km}$ and are grade I earthquake location (a state-specified standard used in seismic networks in China for specifying the quality of earthquake location in which grade I refers to the epicenter and depth uncertainties less than $5 \mathrm{~km}$ and $10 \mathrm{~km}$, respectively). Zhang et al. (2002) concluded that the focal depths of about $90 \%$ of the earthquakes in western China are located at $5 \mathrm{~km}$ to $34 \mathrm{~km}$. Zhang et al. (2002), however, find an average focal depth of $18 \mathrm{~km}$, with $68 \%$ of the earthquakes located between $10 \mathrm{~km}$ to $26 \mathrm{~km}$. The results obtained in this study indicate an average focal depth of $11 \mathrm{~km}$, with about $91 \%$ events 


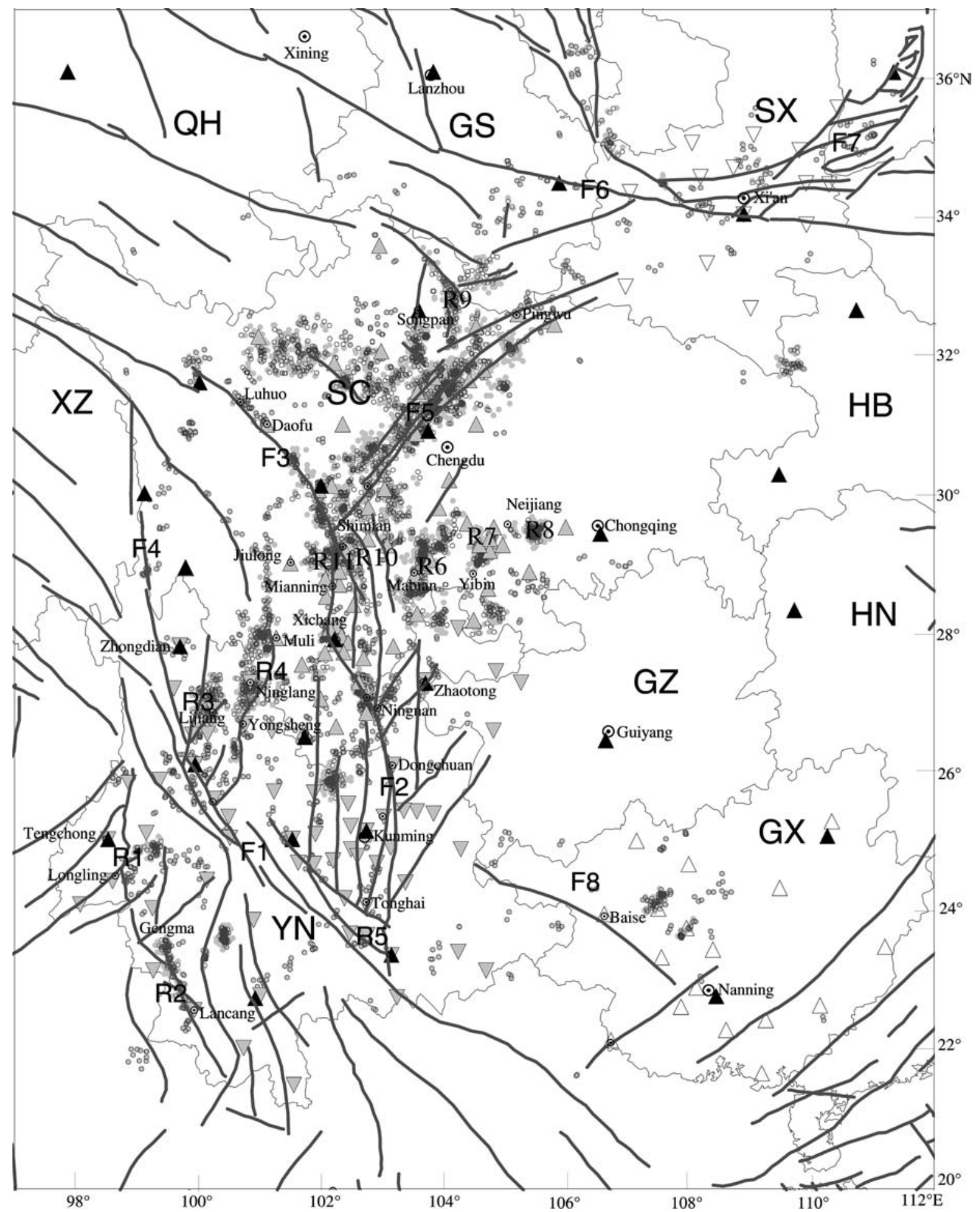

Figure 4. Epicentral distribution of all the 6,496 relocated earthquakes in central-western China using the double-difference algorithm. Open circles represent relocated events. Gray circles represent the same 6,496 events before relocation. Note that in the figure events before relocation are rather diffuse and that many of the relocated events are overlapped. Other symbols as in Figure 2. 

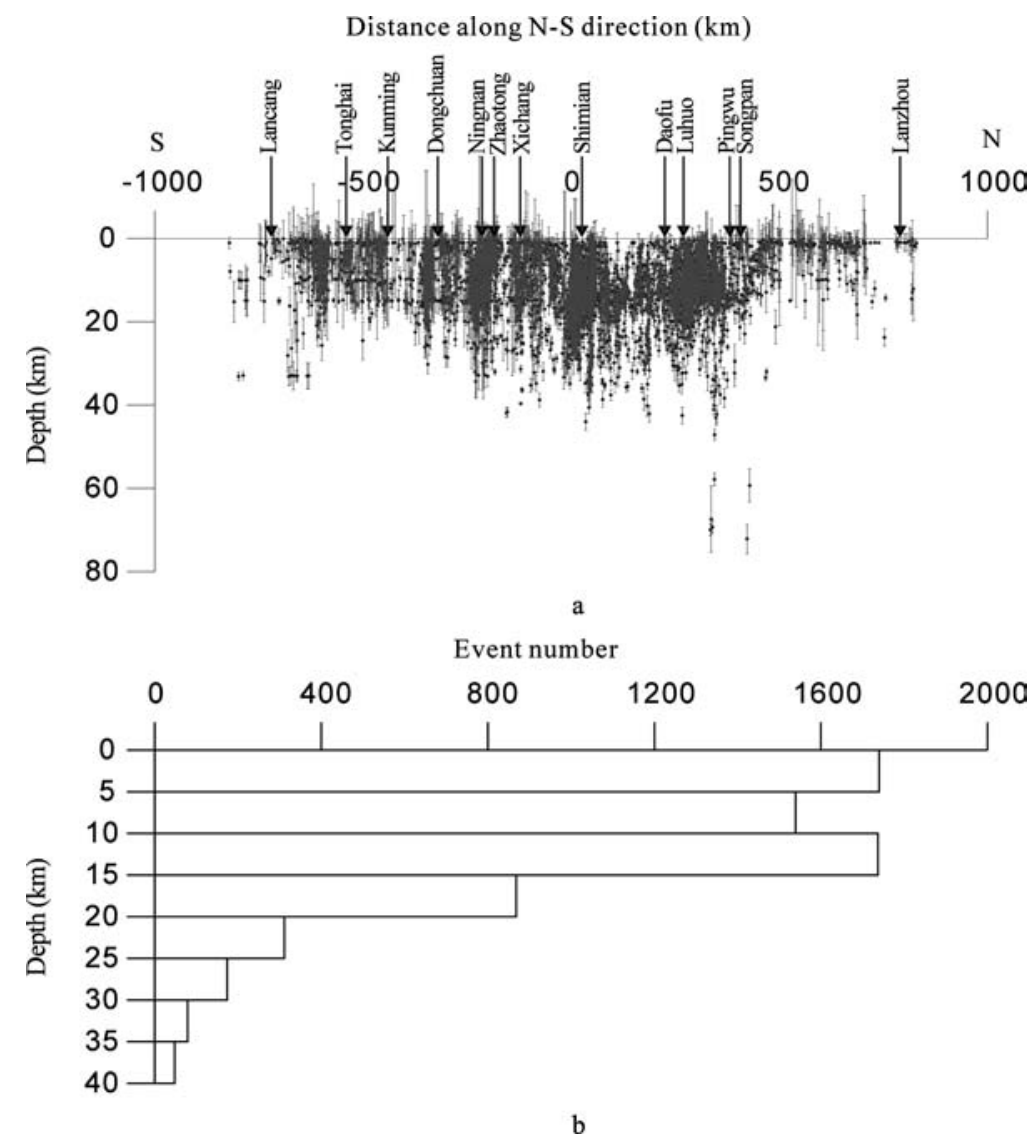

Figure 5. (a) Vertical cross-section of focal depths and uncertainties of all the 6,496 relocated earthquakes in central-western China along the S-N direction; (b) Histogram of the focal depth distribution of the relocated earthquakes in central-western China using the double-difference algorithm. Solid circles and error-bars represent the relocated focal depths and uncertainties, respectively. The reference point is $29.00^{\circ} \mathrm{N}$ and $105.00^{\circ} \mathrm{E}$.

located in the depth range from 0 to $20 \mathrm{~km}$, and about $77 \%$ events in the depth range from 0 to $15 \mathrm{~km}$. This indicates that earthquakes in central-western China are of shallower depth and fall in a narrower depth range than that reported in previous studies.

\section{Discussion}

The improved locations obtained in this study provide important constraints for studies of the lithosphere in general and the seismogenic layer in particular. The lithosphere consists of two layers: the seismogenic upper layer, or schizosphere, characterized by elastobrittle deformation, and the aseismic lower layer, or plastosphere (Scholz, 1982, 1990), in which ductile deformation is predominant. The seismogenic layer along the San Andreas Fault Zone in California, for example, features an average thickness of about $15 \mathrm{~km}$ (Scholz, 1990; Pacheco et al., 1992). The results obtained in this study indicate that the seismogenic layer in central-western China reaches, on average, a depth of about $20 \mathrm{~km}$. With an average crustal thickness of about $45 \mathrm{~km}$ to $50 \mathrm{~km}$ and an average upper crustal thickness of about $20 \mathrm{~km}$ in this area of China (Kan and Lin, 1986; Liu et al, 1989; Sun and Liu, 1991; Fan and Chen, 1992; Wang et al., 2002, 2003), most of the stress appears to be released by brittle failure in the upper crust. It is worthy pointing out that the estimates of seismogenic depths depend on the initial focal depth estimates and the completness of the catalog. The estimates of seismogenic depths in central-western China in this study are superior to that reported in previous studies; however, further study is needed using a more complete catalog and more accurate initial depth estimates. In the following we analyze the hypocentral 
distribution along the major seismic belts in order to understand the dimensions and depth extensions of the active faults, and we explore their correlation with past large earthquakes and the relocated seismicity.

\section{Lancang-Gengma seismic belt (R2)}

On November 6, 1988, two earthquakes with $M_{\mathrm{S}} 7.4$ and $M_{\mathrm{S}} 7.2$ (Nos. 50 and 51 in Figure $1 \mathrm{~b}$ and Table A1) occurred along this fault system within $12 \mathrm{~min}$ (Figure 1b). The Lancang earthquake of $M_{\mathrm{S}} 7.4$ (No. 50 in Figure 6a) ruptured the southern part of this fault; while the Gengma earthquake of $M_{\mathrm{S}} 7.2$ (No. 51 in
Figure 6a) ruptured the northern part about $60 \mathrm{~km}$ to the NW of the Lancang earthquake. Focal mechanisms indicate that both earthquakes are mainly right-lateral strike-slip events (Chen and Wu, 1989; Mozaffari et al., 1998). The fault plane of the Lancang earthquake strikes at $144^{\circ}$ and dips $79^{\circ}$ towards SW, while the Gengma earthquake indicates a strike of $158^{\circ}$ and a dip of $77^{\circ}$ towards SW (Jiang, 1993). Aftershocks located by the Yunnan Province Seismic Network (YNSN) show a $175^{\circ}$ (NNW-SSE) trend, $120 \mathrm{~km}$ long and $50 \mathrm{~km}$ wide band, strongly correlating with the rupture areas of the Lancang and Gengma events and with the background seismicity (Jiang, 1993). The relocations obtained in this study define a $150 \mathrm{~km}$ long and $40 \mathrm{~km}$

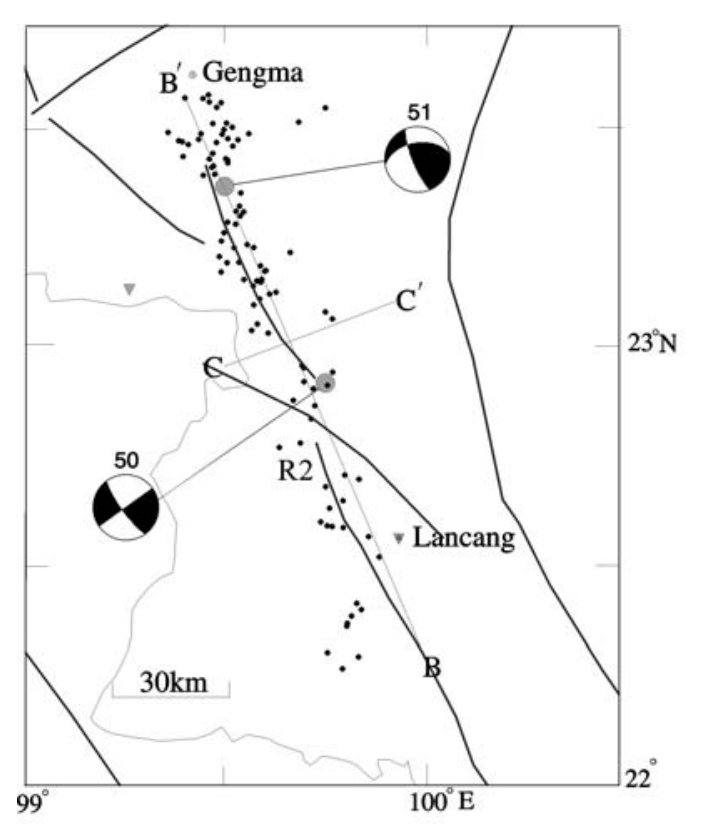

a

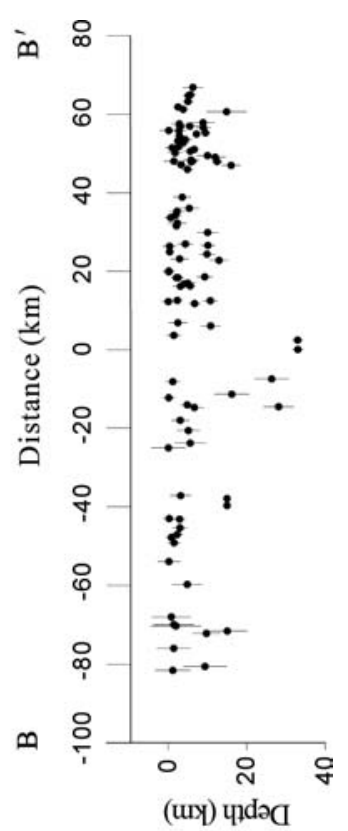

b

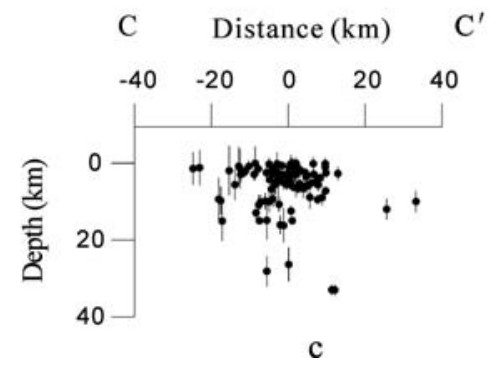

Figure 6. Relocated hypocentral distribution of seismicity (1992-1999) along the Lancang-Gengma seismic belt (R2). (a) Epicentral distribution of relocated earthquakes. Solid circles represent relocated epicenters of earthquakes, upside-down gray triangles indicate seismic stations, thick solid lines are surface traces of active faults. Focal mechanisms are shown for the two 1988 Lancang-Gengma earthquakes (gray circles) of $M_{\mathrm{S}} 7.4$ (No. 50) and $M_{\mathrm{S}} 7.2$ (No. 51). (b) Vertical cross-section along the profile B-B' showing focal depths and uncertainties of the relocated earthquakes along $\mathrm{N} 25^{\circ} \mathrm{W}$ direction. (c) Vertical cross-section along the profile $\mathrm{C}-\mathrm{C}^{\prime}$ showing focal depths and uncertainties of the relocated earthquakes along $\mathrm{N} 65^{\circ} \mathrm{E}$ direction. Solid circles and error-bars in (b) and (c) represent the relocated focal depths and uncertainties, respectively. The reference point is $23.00^{\circ} \mathrm{N}$ and $99.60^{\circ} \mathrm{E}$. 
wide band (Figure 6a) that coincides with the aftershock area $(130 \mathrm{~km} \times 50 \mathrm{~km})$ of the 1988 LancangGengma earthquakes and with the surface traces of mapped faults. The relocated focal depths fall in the range from 0 to $30 \mathrm{~km}$ (Figures $6(\mathrm{~b} \mathrm{\&} \mathrm{c)}$ ), with the deepest events occurring near the transition zone between the northern and southern segments. These features indicate that the relocated seismicity in this belt is clearly related to the same seismogenic structure as that of the 1988 Lancang-Gengma earthquakes.

\section{Lijiang seismic belt (R3)}

The N-S trending Lijiang seismic belt (R3) is bounded by the Lijiang Basin. About 450 aftershocks with $M_{\mathrm{L}} \geq$ 2.5 followed the $M_{\mathrm{S}} 7.0$ event (No. 52 in Figure $1 \mathrm{~b}$ and Table 1) from February 3, 1996 until December 1996. According to an investigation by Western Yunnan Earthquake Prediction Experiment Site, Seismological Bureau of Yunnan Province (1998, hereafter cited as WYEPES), the epicentral location of the mainshock did not correlate with any previously known major fault in this area, nor did the epicentral distribution of the mainshock and larger aftershocks appear to colocate with the observed surface rupture produced by the mainshock. Field investigations revealed that the surface rupture was about $30 \mathrm{~km}$ long and the maximum horizontal and vertical offsets were $30-50 \mathrm{~cm}$ and 25-40 cm, respectively (WYEPES, 1998). The meizoseismal area shows a maximum intensity area of grade IX on the Chinese Earthquake Intensity Scale (roughly equivalent to Modified Mercalli Earthquake Intensity Scale), with major and minor axes of $75 \mathrm{~km}$ and $25 \mathrm{~km}$ length in N-S and E-W directions (Figure 7a), respectively. The epicenters (open circles denoted by CNSN and YNSN in Figure 7a) of the Lijiang earthquake determined by both the CNSN and the YNSN are located at the northern portion of the meizoseismal area, near the isoseismal contour marking the transition from intensity grade IX to grade VIII. The double-difference location of the mainshock (gray solid circles denoted by DD in Figure 7a) locates near the center of the area with intensity grade IX, which also coincides with the area (open circles denoted by XC in Figure 7a) where maximum dislocation was obtained from waveform inversion (Xu and Chen, 1998). As mentioned above, the 1996 Lijiang earthquake and its aftershock sequence are included in the relocation. The relocated epicenters are distributed in an area of $70 \mathrm{~km}$ length and $40 \mathrm{~km}$ width; most of the relocated earthquakes are of focal depths less than $30 \mathrm{~km}$, and roughly show two conju- gate planes, one dipping east and the another dipping west, both of which are a fit to the $\mathrm{N}-\mathrm{S}$ striking, normal dip-slip focal mechanism of the mainshock (Figures $7(\mathrm{a}-\mathrm{c}))$.

Yongsheng-Ninglang-Muli-Jiulong seismic belt (R4)

As shown in Figure 8a, the nearly N-S trending Yongsheng-Ninglang-Muli-Jiulong seismic belt (R4) consists of three segments: a southern segment (from $26.2^{\circ} \mathrm{N}$ to $26.9^{\circ} \mathrm{N}$ ), a central segment (from $26.9^{\circ} \mathrm{N}$ to $28.1^{\circ} \mathrm{N}$ )), and a northern segment (from $28.1^{\circ} \mathrm{N}$ to $29.5^{\circ} \mathrm{N}$ ). The central and southern segments of the Yongsheng-Ninglang-Muli-Jiulong seismic belt (R4) as exposed at the surface has a length of $210 \mathrm{~km}$ (from $26.2^{\circ} \mathrm{N}$ to $28.1^{\circ} \mathrm{N}$ ) and a width of about $50 \mathrm{~km}$ (from $100.6^{\circ} \mathrm{E}$ to $101.1^{\circ} \mathrm{E}$ ) and is known as the YongshengNinglang seismic belt. The relocated hypocenters indicate that this seismic belt probably extends at least $150 \mathrm{~km}$ further to the north and terminates at about $29.5^{\circ} \mathrm{N}$ (Figure 8a). The northward extending segment is known as the Muli-Jiulong seismic belt. It has a width of about $20 \mathrm{~km}$ (roughly from $101.0^{\circ} \mathrm{E}$ to $101.2^{\circ} \mathrm{E}$ ), compared to a width of about $50 \mathrm{~km}$ along the central and southern segments. On the central part, the active faults mapped previously by field geological study (Li and Wang, 1975; Guo, 1984) define an arc of about $120 \mathrm{~km}$ long (roughly from $26.9^{\circ} \mathrm{N}$ to $28.1^{\circ} \mathrm{N}$ ) which in part is convex to the east (see fault traces in Figures $1 \mathrm{~b}$ and $8 \mathrm{a})$. While the epicentral distribution of the relocated earthquakes in the southern segment trend approximately north and correlate directly to the surface trace of the fault, the earthquakes in the central and northern segments trend also approximately north but do not correlate directly to the surface trace of the fault. At the surface, no fault is currently mapped in the central segment of the seismic belt. Relative to the central segment (from $26.9^{\circ} \mathrm{N}$ to $28.1^{\circ} \mathrm{N}$ ) of the seismic belt, the previously mapped fault is located about $30 \mathrm{~km}$ to the east. Relative to the northern segment (from $28.1^{\circ} \mathrm{N}$ to $29.5^{\circ} \mathrm{N}$ ) of the seismic belt, the previously mapped fault is located about $50 \mathrm{~km}$ to the west. The striking difference between the epicentral distribution and location of the previously mapped faults in both the northern and the central segments of the Yongsheng-Ninglang-MuliJiulong seismic belt was not due to a systematic error in the relocation process. Thus the relocated epicenters indicate that as a whole the Yongsheng-NinglangMuli-Jiulong seismic belt (R4) is nearly N-S trending, is broader to the south of Muli and narrower to the north of Muli, and the structure imaged by the relocated 


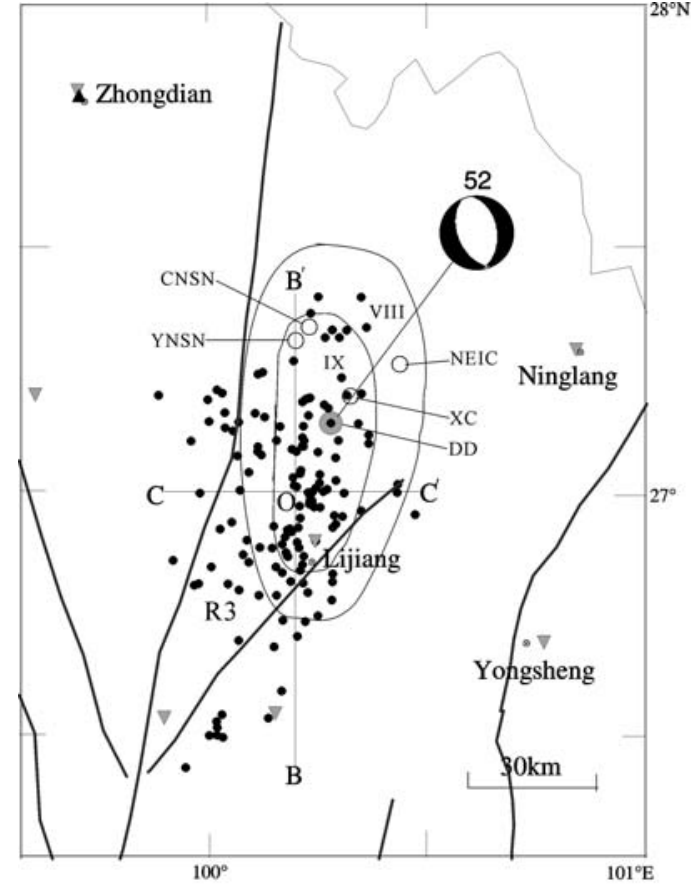

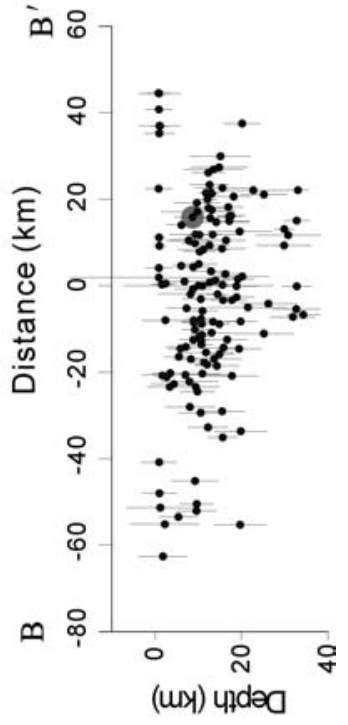

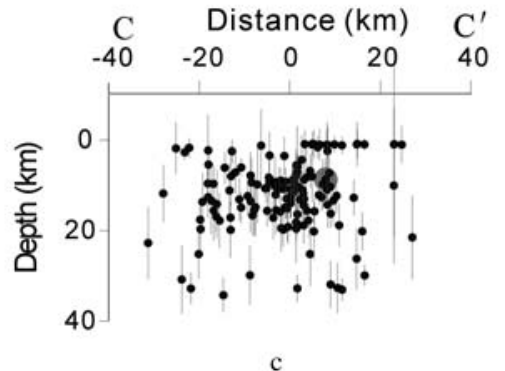

Figure 7. The 1996 Lijiang earthquake of $M_{\mathrm{S}} 7.0$ and relocated hypocentral distribution of seismicity within the Lijiang seismic belt (R3). (a) Epicentral location, isoseismals, focal mechanism of the 1996 Lijiang earthquake and epicentral distribution of relocated earthquakes in the Lijiang seismic belt; (b) Vertical cross-section along the profile B-B' showing focal depths and uncertainties of the relocated earthquakes along S-N direction; (c) Vertical cross-section along the profile C-C' showing focal depths and uncertainties of the relocated earthquakes along W-E direction. Solid circles and error-bars in (b) and (c) represent the relocated focal depths and uncertainties, respectively. Open circles denoted by NEIC, CNSN, YNSN and XC show epicentral locations given by NEIC, YNSN, CNSN, and Xu and Chen (1998), respectively. Gray solid circle shows relocated epicenter of the Lijiang earthquake of $M_{\mathrm{S}} 7.0$ obtained in this study. The reference point is $27.00^{\circ} \mathrm{N}$ and $100.20^{\circ} \mathrm{E}$.

earthquakes in the central and southern segments of the seismic belt from $26.2^{\circ} \mathrm{N}$ to $28.1^{\circ} \mathrm{N}$ is likely to image a blind active fault.

The Yongsheng-Ninglang-Muli-Jiulong seismic belt (R4) and the above-mentioned Lijiang seismic belt (R3) are within the Sichuan-Yunnan diamond-shaped tectonic block (Figure 9). Recent field geological study (Xu et al., 2003) suggests that an NE trending active fault, the Xiaojinhe-Lijiang fault, is likely cutting through the Sichuan-Yunnan diamond-shaped tectonic block and dividing the block into two sub-blocks, the southern and northern sub-blocks (Figure 9). Along the Xiaojinhe-Lijiang fault, various kinds of offset landforms have developed, showing that the fault is dominated by left-lateral strike-slip with minor reverse dipslip components in the late Quaternary. As Figures 4 and 9 shown, the epicenters of relocated earthquakes within the Sichuan-Yunnan diamond-shaped tectonic block have not indicated a clear lineation associated with the NE trending Xiaojinhe-Lijiang fault. Instead, 


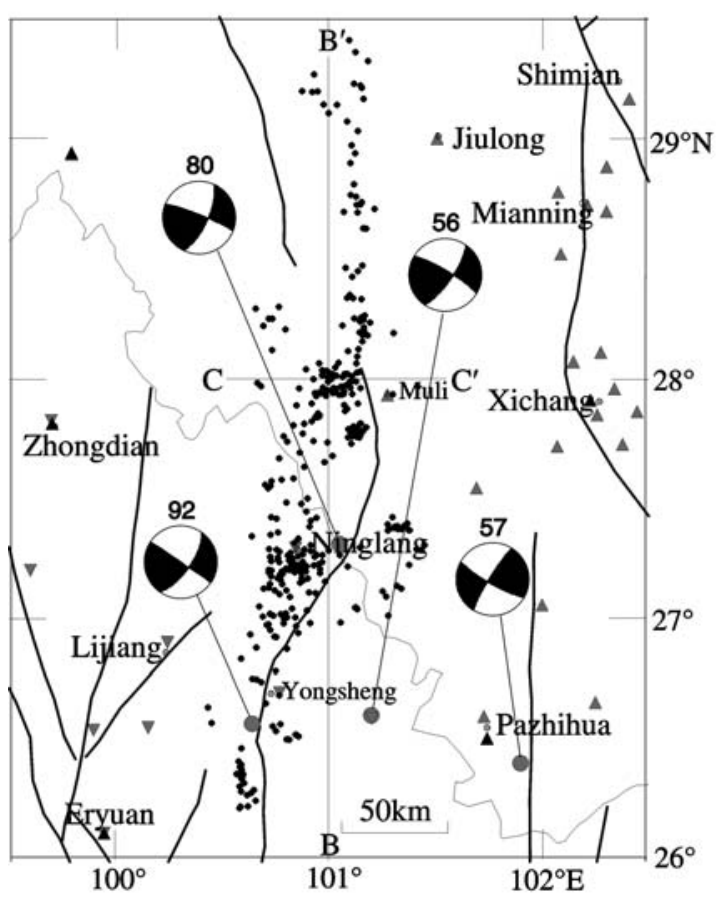

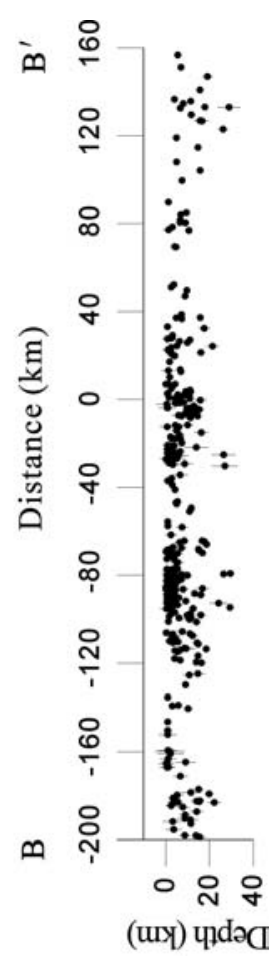

b

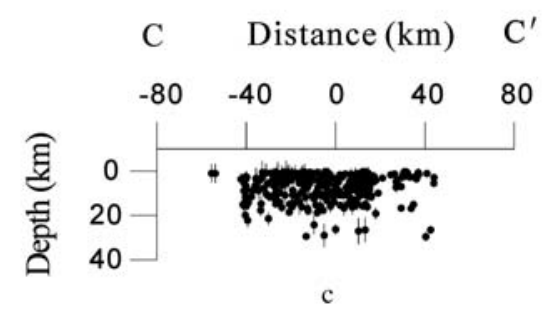

Figure 8. Relocated hypocentral distribution of Yongsheng-Ninglang-Muli-Jiulong seismic belt (R4). (a) Epicentral distribution of relocated earthquakes (solid circles) and focal mechanisms of earthquakes Nos. 56, 57, 90 (gray solid circles); (b) Vertical cross-section along the profile B-B' showing focal depths and uncertainties of the relocated earthquakes along S-N direction; (c) Vertical cross-section along the profile C-C' showing focal depths and uncertainties of the relocated earthquakes along W-E direction. Solid circles and error-bars in (b) and (c) represent the relocated focal depths and uncertainties, respectively. The reference point is $28^{\circ} \mathrm{N}$ and $101^{\circ} \mathrm{E}$.

both the Lijiang (R3) and the Yongsheng-NinglangMuli-Jiulong (R4) seismic belts are two nearly parallel, N-S trending seismic belts. The focal mechanisms of earthquakes Nos. 56, 80, 92 show a NW to NNW compression (Figure 8a), and have one of the nodal planes nearly NNE striking, in good agreement with the overall trend of the Yongsheng-Ninglang-Muli-Jiulong seismic belt (R4) and mainly left-lateral strike-slip faulting with minor reverse dip-slip components. The earthquakes Nos. 56, 57 and 80, as well as the more recent $M_{\mathrm{S}} 6.0$ earthquake (No. 92) of October 27, 2001, were not included in this relocation study. Thus the relationship between the seismicity of the Yongsheng-
Ninglang-Muli-Jiulong seismic belt (R4), the Lijiang seismic belt (R3) and the Xiaojinhe-Lijiang Fault as suggested by $\mathrm{Xu}$ et al. (2003), and the occurrences of major earthquakes within the interior of the SichuanYunnan diamond-shaped tectonic block remains unsolved and need further study.

Longmenshan (F5), Mabian (R6), Yibin (R7), Neijiang (R8) seismic belts

As shown in Figure 2, the Sichuan (SC) region has the highest levels of seismicity in the study area. The epicentral distribution of the routine earthquake locations 


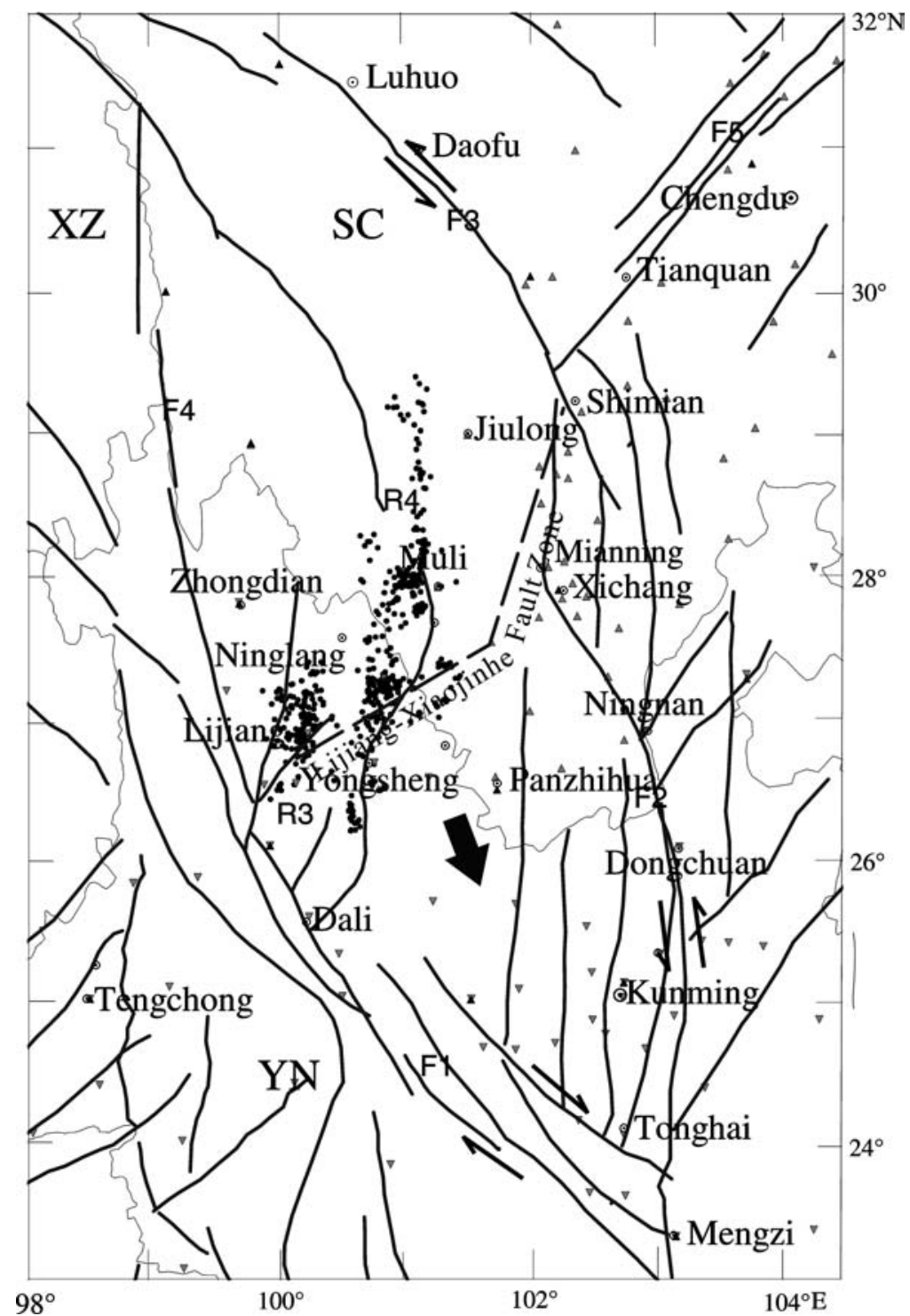

Figure 9. Yongsheng-Ninglang-Muli-Jiulong seismic belt (R4), Lijiang seismic belt (R3), and NE trending Xiaojinhe-Lijiang Fault (thick gray dash lines) as suggested by Xu et al. (2003). Other symbols as in Figures 2 and 4.

in this region is diffuse across an extensive area (see F5, R6, R7, R8, R9, R10 and R11 in Figure 2), and no clear correlation between the microseismicity and the mapped active faults in this region emerges. After relocation, however, distinct lineation is revealed that can be associated with the Longmenshan seismic belt (F5), the Mabian seismic belts (R6), the Yibin seismic belts (R7), and the Neijiang structure (R8) (Figures 4 and 10). All the 1,398 relocated events along the Longmenshan Fault are distributed within a band of $470 \mathrm{~km}$ length and $100 \mathrm{~km}$ width. The band clearly coincides with the $\mathrm{N} 40^{\circ} \mathrm{E}$ strike of the faults in this belt. Vertical cross-sections of focal depths indicate that the relocated hypocenters are mainly distributed in a layer not deeper than $30 \mathrm{~km}$ (Figures 10(b \& c)).

Seismicity in the Mabian area (R6 in Figure 2) is characterized by a temporal clustering of earthquakes. From December 1935 to May 1936, a cluster of 11 earthquakes with $M 6$ to $M 6.8$ occurred in this area (Wang et al., 1999). Another cluster, consisting of 12 events with $M_{\mathrm{S}} 4.6$ to $M_{\mathrm{S}} 5.9$, occurred in this area from August to November of 1971 (Wang et al., 1999). 


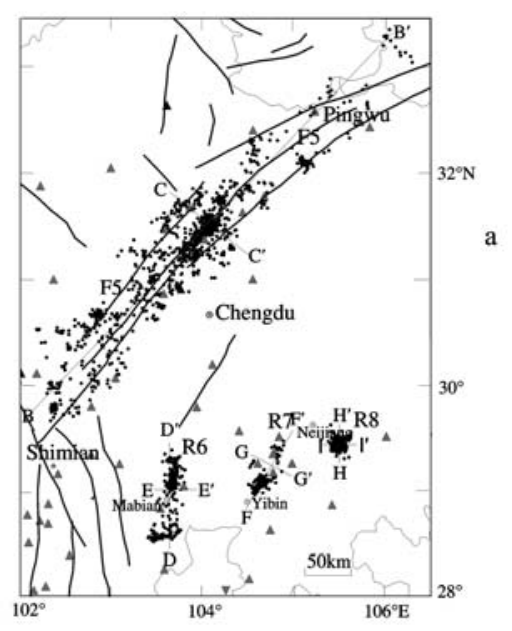

Distance $(\mathrm{km})$

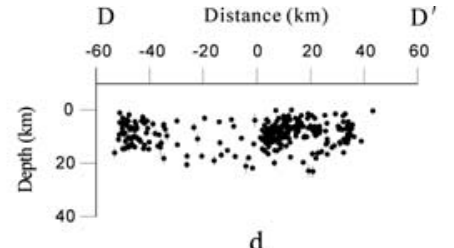

d

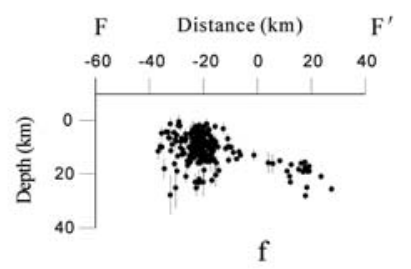

$\mathrm{H}$ Distance $(\mathrm{km}) \quad \mathrm{H}^{\prime}$

B $^{\prime}$

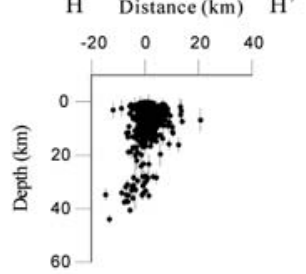

h

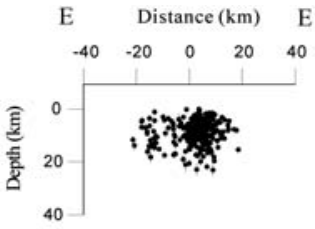

e

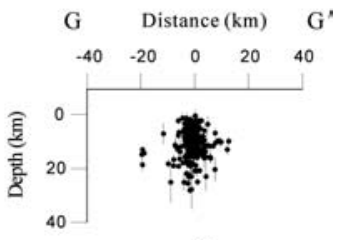

g

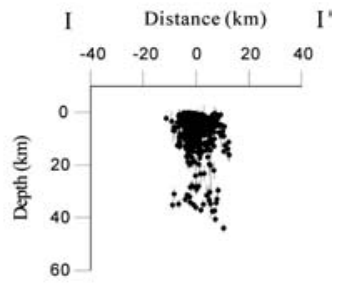

i

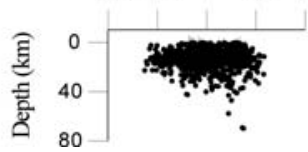

c

Figure 10. Focal depth distribution of the relocated earthquakes in several seismic belts. (a) Epicentral distribution of relocated earthquakes (solid circles); (b) Vertical cross-section along the profile B-B' showing focal depths and uncertainties of the relocated earthquakes along SW-NE direction of the Longmenshan seismic belt (F5); (c) Vertical cross-section along the profile C-C ${ }^{\prime}$ showing focal depths and uncertainties of the relocated earthquakes along NW-SE direction of the Longmenshan seismic belt (F5); (d) Vertical cross-section along the profile D-D' showing focal depths and uncertainties of the relocated earthquakes along S-N direction of the Mabian seismic belt (R6); (e) Vertical cross-section along the profile E-E' showing focal depths and uncertainties of the relocated earthquakes along W-E direction of the Mabian seismic belt (R6); (f) Vertical cross-section along the profile $\mathrm{F}_{-} \mathrm{F}^{\prime}$ showing focal depths and uncertainties of the relocated earthquakes along $\mathrm{N} 30^{\circ} \mathrm{E}$ direction of the Yibin seismic belt (R7); (g) Vertical cross-section along the profile G-G' showing focal depths and uncertainties of the relocated earthquakes along $\mathrm{N} 120^{\circ} \mathrm{E}$ direction of the Yibin seismic belt (R7); (h) Vertical cross-section along the profile H-H' showing focal depths and uncertainties of the relocated earthquakes along S-N direction of the Neijiang seismic belt (R8); (i) Vertical cross-section along the profile I-I' showing focal depths and uncertainties of the relocated earthquakes along W-E direction of the Neijiang seismic belt (R8). Solid circles and error-bars in (b) through (i) represent the relocated focal depths and uncertainties, respectively. The reference points for the Longmenshan, Mabian, Yibin and Neijiang seismic belts are $\left(31.53^{\circ} \mathrm{N}, 104.10^{\circ} \mathrm{E}\right),\left(29.00^{\circ} \mathrm{N}, 103.62^{\circ} \mathrm{E}\right),\left(29.25^{\circ} \mathrm{N}, 104.76^{\circ} \mathrm{E}\right)$ and $\left(29.44^{\circ} \mathrm{N}, 105.49^{\circ} \mathrm{E}\right)$, respectively. $^{\circ}$

Double-difference relocations of the recent seismicity (Figures 4 and 10(a, d \& e)) indicate a clear N-S trending lineation feature that coincides with the assumed locations of the two clusters of moderate size earthquakes. The relocated focal depths are mainly in the range of 0 to $20 \mathrm{~km}$ (Figure $10(\mathrm{~d} \mathrm{\&} \mathrm{e)})$. East of the Mabian seismic belt (R6) are the Yibin seismic belt (R7 in Figures 4 and 10) and the Neijiang seismic belt (R8 in Figures 4 and 10). The Mabian seismic belt (R6) is about $70 \mathrm{~km}$ long and $20 \mathrm{~km}$ wide and the Neijiang seismic belt (R8) is about $30 \mathrm{~km}$ long and $20 \mathrm{~km}$ wide. Relocated earthquakes of both belts (Figures 4 and 10(f-i)) indicate strong spatial clustering, outlining the seismically active parts of the faults. In particular, the relocated focal depths of the Yibin seismic belt exhibits two clusters, a larger and shallower one in the south and a smaller and deeper one in the north (Figures 10(f and g)), and the relocated focal depths of the Neijiang seismic belt also exhibits two earthquake clusters in the depth direction, one in the shallower range from 0 to $20 \mathrm{~km}$ and another in the deeper range from $20 \mathrm{~km}$ to $40 \mathrm{~km}$. 


\section{Songpan seismic belt (R9)}

Songpan seismic belt (R9 in Figures 2, 4 and 11a) is to the north of the Longmenshan seismic belt (F5 in Figures 2, 4 and 10a). Relocated events along the Songpan seismic belt (R9) indicate a north trending seismic structure that appears to continue along a more NW trending fault system (Figure 11). Several strong earthquakes occurred such as the A. D. 1630 earthquake with $M 6.5$ (epicentral location: $32.6^{\circ} \mathrm{N}, 104.1^{\circ} \mathrm{E}$ ) (Min, 1995) and the August 16, 22 and 23, 1976, earthquakes with $M_{\mathrm{S}} 7.2$ (No. 47), $M_{\mathrm{S}} 6.7$ (No. 78) and $M_{\mathrm{S}} 7.2$ (No. 48) (Seismological Bureau of Sichuan Province, 1979), respectively. An investigation of the 1976 Songpan earthquake sequence by the Seismological Bureau of Sichuan Province (1979) indicates that the aftershocks occurred along an elongated area trending NNW, about $70 \mathrm{~km}$ in length and $30 \mathrm{~km}$ in width (rectangle enclosed by thin dashed line in Figure 11a), with the seismogenic fault striking N-S. The epicenters of the relocated earthquakes in this study coincide with the epicentral distribution of these events and their aftershocks. The relocated hypocenters indicate that the Songpan seismic belt extends about $50 \mathrm{~km}$ further to the $\mathrm{N} 40^{\circ} \mathrm{W}$ (Figure 11a), and that most earthquakes in the Songpan seismic belt are located in depth range of 0 to $20 \mathrm{~km}$. A few of them are at greater focal depth, and there is a tendency for deeper events toward the south (Figures 11(b-e)).The focal mechanisms show nearly vertical fault planes, striking $0^{\circ}, 334^{\circ}$ and $325^{\circ}$ for the preferred fault plane of these three events (Figure 11a), respectively. The relocated hypocenters in this study coincide not only with the epicentral distribution of these three events and their aftershocks (Figure 11), but also with the strikes of the preferred fault planes given by fault plane solutions (Figure 11(a-c)).

\section{Shimian and Mianning seismic belts (R10, R11)}

We note that the Shimian and Mianning seismic belts, shown in Figure 12, have focal depths somewhat greater than typical for the broad region. Both belts are located in an area where the Xianshuihe Fault (F3 in Figures 1 and 4) and Xiaojiang Fault (F2 in Figures 1 and 4) meet. After relocation, two seismic belts, Shimian seismic belt (R10 in Figures 1 and 4) and Mianning seismic belt (R11 in Figures 1 and 4), are resolved. The relocation results unambiguously show

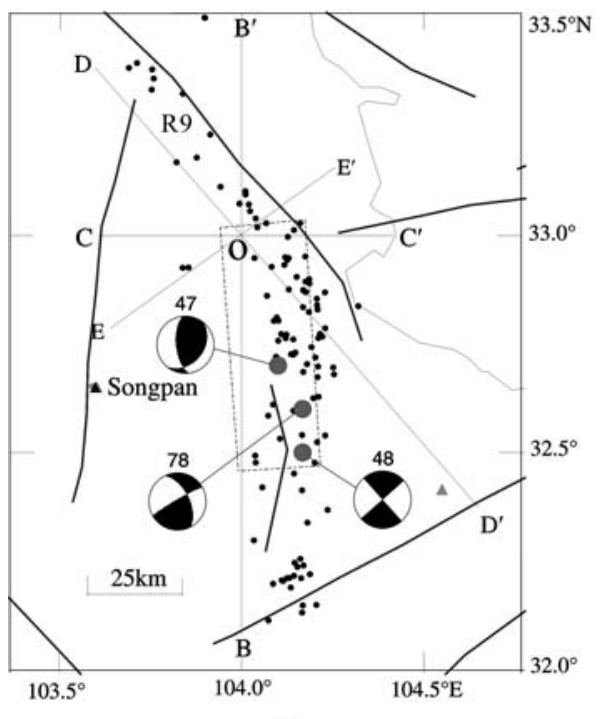

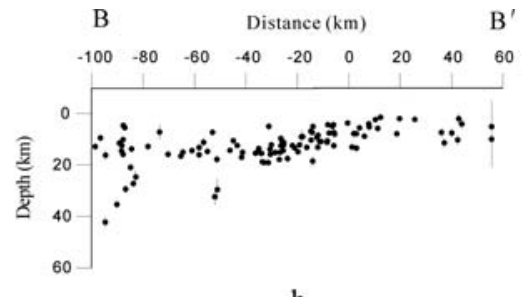

$\mathrm{b}$

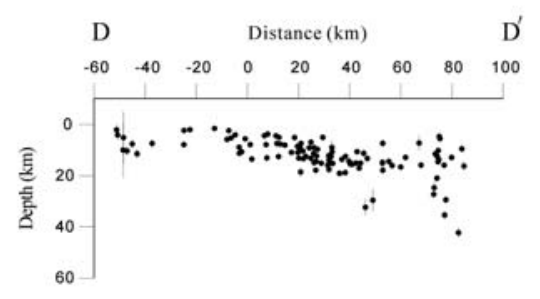

d
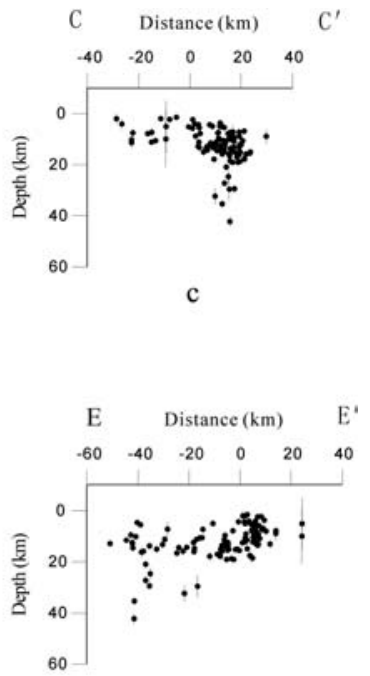

Figure 11. Relocated hypocentral distribution of Songpan seismic belt (R9) and focal mechanisms of the 1976 Songpan earthquakes. (a) Epicentral distribution of relocated earthquakes (solid circles) and focal mechanisms of the 1976 Songpan earthquakes (gray circles); (b) Vertical cross-section along the profile B-B' showing focal depths and uncertainties of the relocated earthquakes along S-N direction of the Songpan seismic belt (R9); (c) Vertical cross-section along the profile C-C' showing focal depths and uncertainties of the relocated earthquakes along E-W direction of the Songpan seismic belt (R9); (d) Vertical cross-section along the profile D-D's showing focal depths and uncertainties of the relocated earthquakes along $\mathrm{N} 40^{\circ} \mathrm{W}$ direction of the Songpan seismic belt (R9); (e) Vertical cross-section of the profile E-E' showing focal depths and uncertainties of the relocated earthquakes along $\mathrm{N}^{\circ} 0^{\circ} \mathrm{E}$ direction of the Songpan seismic belt (R9). Solid circles and error bars represent focal depths and uncertainties, respectively. The reference point for the profiles B-B $\mathrm{B}^{\prime}, \mathrm{C}-\mathrm{C}^{\prime}, \mathrm{D}^{-\mathrm{D}^{\prime}}$ and $\mathrm{E}-\mathrm{E}^{\prime}$ is $33.00^{\circ} \mathrm{N}$ and $104.00^{\circ} \mathrm{E}$. 


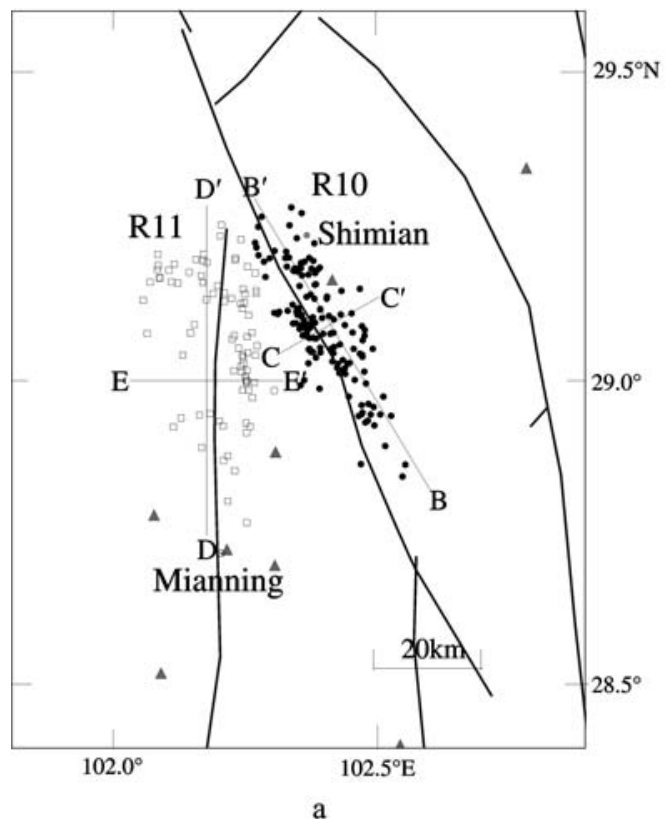

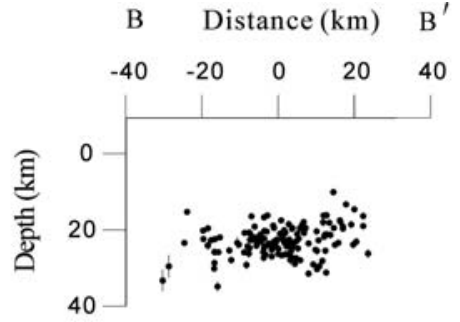

b

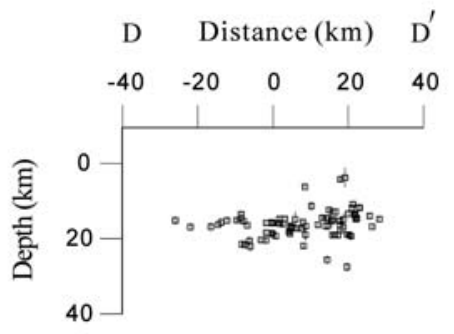

d

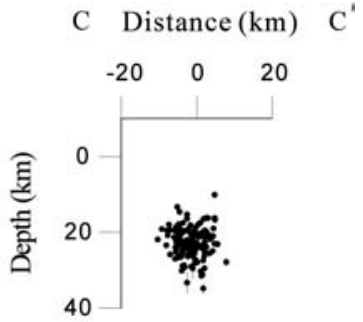

c

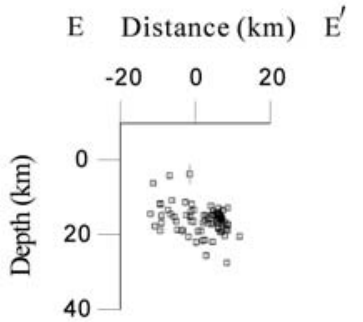

$\mathrm{e}$

Figure 12. Hypocentral distribution of relocated earthquakes of Shimian (R10) and Mianning (R11) seismic belts. (a) Epicentral distribution of relocated earthquakes. Solid circles represent earthquakes of Shimian seismic belts (R10) and open squares represent earthquakes of Mianning seismic belts (R11). (b) Vertical cross-section along the profile B-B' showing focal depths (solid circles) and uncertainties (error bars) of the relocated earthquakes along $\mathrm{N} 30^{\circ} \mathrm{W}$ direction in Shimian seismic belt. (c) Vertical cross-section along the profile C-C $\mathrm{C}^{\prime}$ showing focal depths (solid circles) and uncertainties (error bars) of the relocated earthquakes along N60 E direction in Shimian seismic belt. (d) Vertical cross-section along the profile D-D' showing focal depths (open squares) and uncertainties (error bars) of the relocated earthquakes along S-N direction in Mianning seismic belt. (e) Vertical cross-section along the profile E-E' showing focal depths (open squares) and uncertainties (error bars) of the relocated earthquakes along W-E direction in Mianning seismic belt. The reference points for Shimian and Mianning seismic belts are (29.09 $\mathrm{N}$, $\left.102.41^{\circ} \mathrm{E}\right)$ and $\left(29.00^{\circ} \mathrm{N}, 102.18^{\circ} \mathrm{E}\right)$, respectively.

that essentially the Shimian seismic belt (R10) in the east is the northern segment of the Xiaojiang Fault and trends $330^{\circ}\left(\mathrm{N} 30^{\circ} \mathrm{W}\right)$, and the Mianning seismic belt in the west is the northern segment of Anninghe Fault and trends N-S (R11 in Figures 1 and 4). In the north, the Mianning seismic belt merges into the Shimian seismic belt. The focal depths of these two seismic belts are relatively deep (Figures 12(be)). The earthquakes are distributed predominately in the depth range from $15 \mathrm{~km}$ to $35 \mathrm{~km}$ for the Shimian seismic belt (Figures 12(b \& c)) and from $10 \mathrm{~km}$ to $25 \mathrm{~km}$ for the Mianning seismic belt, respectively (Figures 12(d \& e)).

\section{Conclusions}

In this study the double-difference technique (Waldhauser and Ellsworth, 2000) has been applied to earthquakes in central-western China from $21^{\circ} \mathrm{N}$ to $36^{\circ} \mathrm{N}$ and $98^{\circ} \mathrm{E}$ to $111^{\circ} \mathrm{E}$, to obtain a clearer view of seismicity distribution. It is demonstrated that the seismicity pattern based on the routine earthquake location is diffuse and shows ambiguous features, and is not well correlated to the expression of active faults at the surface. For most seismic belts of central-western China, such as Lancang-Gengma, Lijiang, YongshengNinglang-Mnli-Jiulong, Lonmenshan, Mabian, Yibin, Neijiang, Songpan, Shimain and Mianning seismic belts, we find a close relationship between the relocated seismicity and the expression of active faults at the surface in general. But for some seismic belts of the study area, such as the central and northern segments of the Yongsheng-Ninglang-Muli-Jiulong seismic belt and the Xiaojinhe-Lijiang Fault, we find a significant difference between the epicentral distribution of relocated earthquakes and locations of the mapped faults. In such cases, the relocated seismicity is clustered and can be interpreted the presence of active faults. Moreover, our relocated events allow to indicate the Shimian seismic belt and Mianning seismic belt as distinct features. 
We find most earthquakes are distributed between depths of 0 to $20 \mathrm{~km}$, indicating that the thickness of the seismogenic layer in this region is less than $20 \mathrm{~km}$. However, earthquakes with deeper focal depth, such as earthquakes of the Neijiang seismic belt with focal depths from 0 to $40 \mathrm{~km}$, are also found in some locations. These results provide important constraints for studies of the seismogenic layer, and for the mechanism of earthquake generation in centralwestern China.

\section{Acknowledgments}

The authors would like to thank two anonymous reviewers for their constructive comments and the authors would like to thank the Monitoring Center of the Seismological Bureau of Yunnan Province, Monitoring Center of the Seismological Bureau of Sichuan Province, Seismological Bureau of Shaanxi Province, Seismological Bureau of Guangxi Province and the Sub-Center of China National Digital Seismic Net- work, Institute of Geophysics, China Seismological Bureau, for providing the observational data of seismic networks. We would also like to acknowledge Dr. Yu Xiangwei and Ms. Zheng Yuejun for their help in data pre-processing for this study, and Ms. Shen Siwei, Mr. Chen Shulin and Ms. Long Xiaofan, Seismological Bureau of Yunnan Province, and Ms. Feng Dongying, Institute of Crustal Dynamics, China Seismological Bureau, for their help in data collection for this study. This study is sponsored by the key project "Process, Mechanism and Prediction of Geological Hazard" (2001CB711005-1-3) and the project "Mechanism and Prediction of Continental Earthquakes" of Ministry of Science and Technology, People's Republic of China (G19980407/95-13-02-04). Contribution No.04FE1011, Institute of Geophysics, China Seismological Bureau.

\section{Appendix}

See Table A1. 


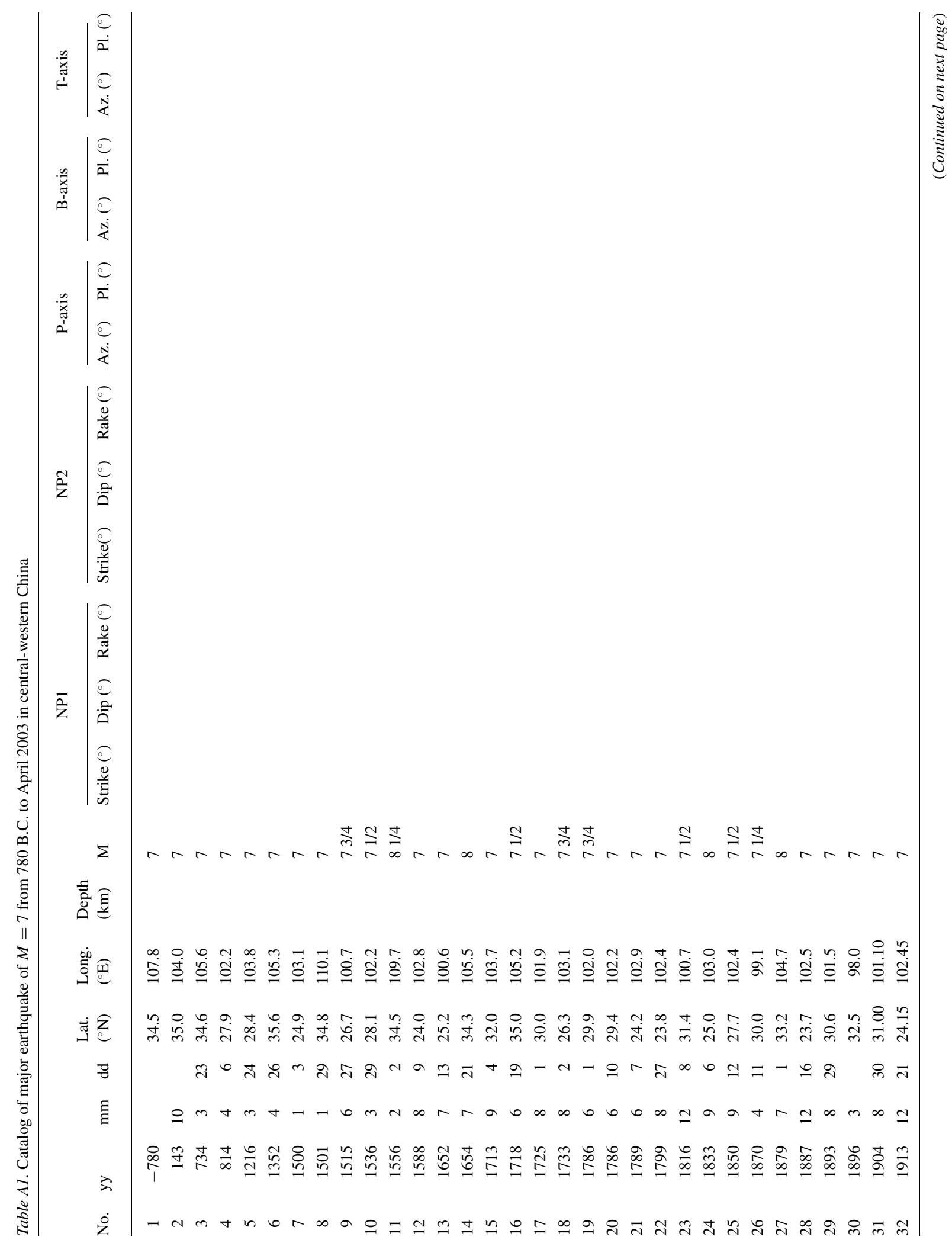




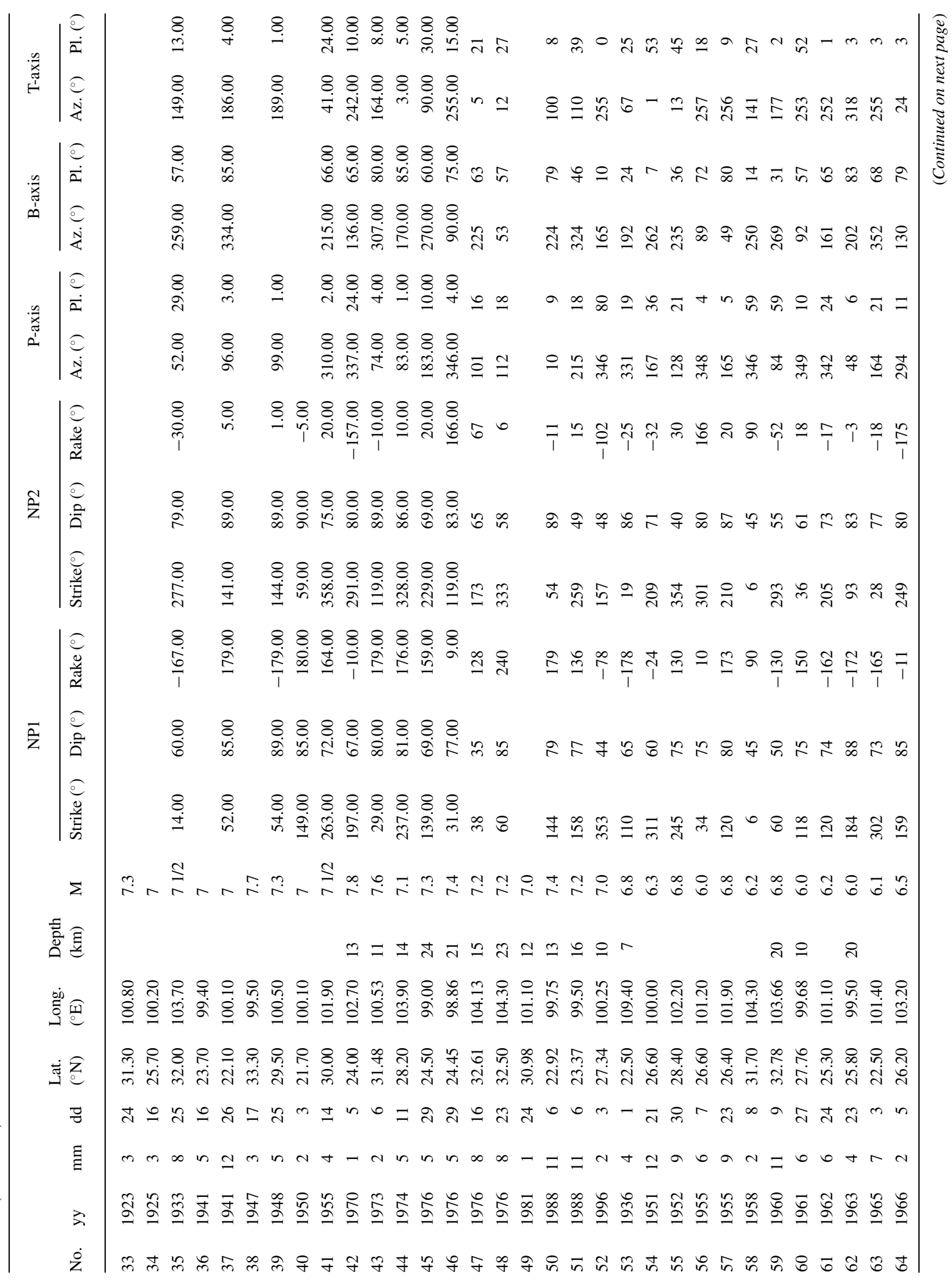




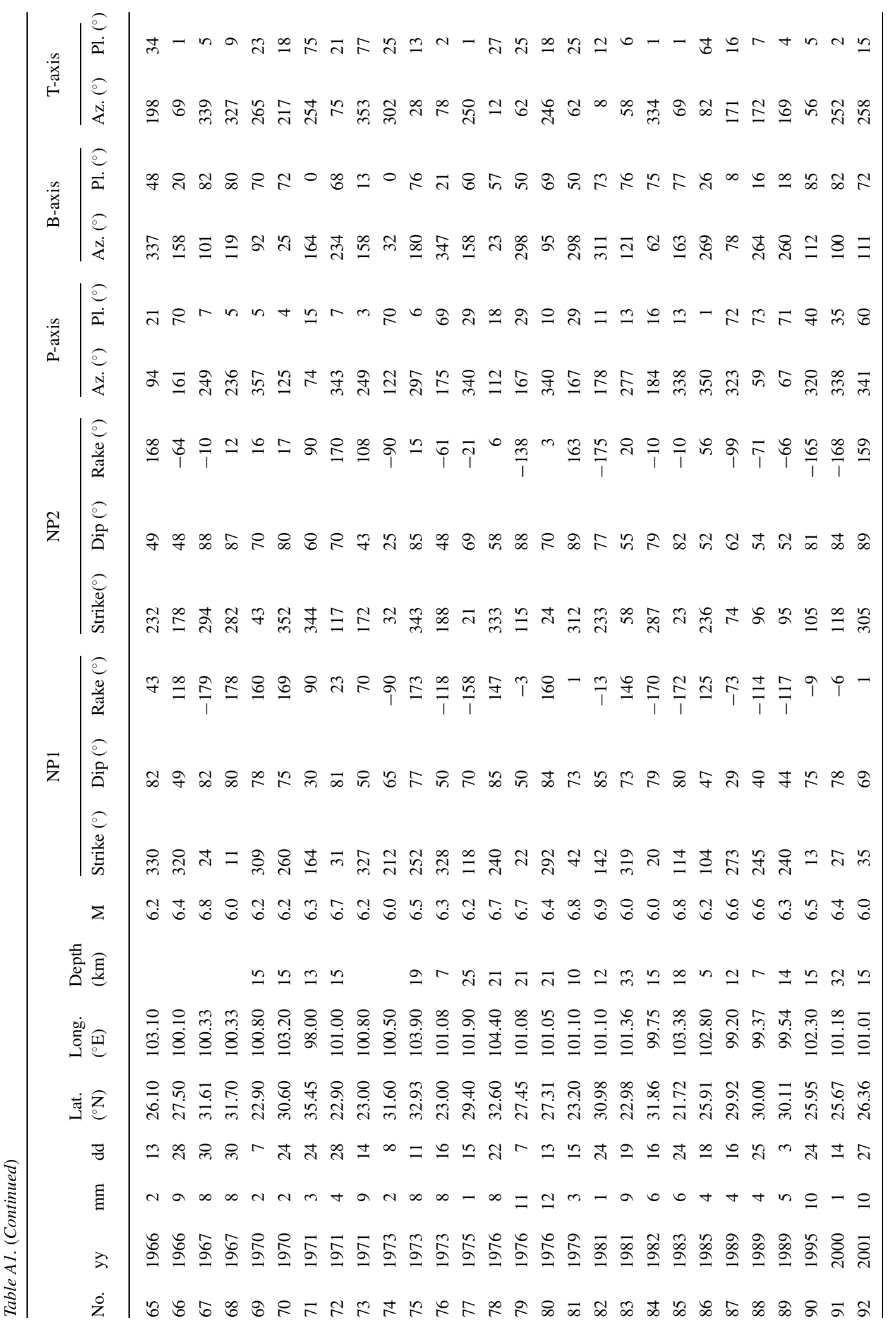




\section{References}

Chen, Y.T. and Wu, F.T., 1989, Langcang-Gengma earthquake. A preliminary report on the November 6, 1988 event and its aftershocks, Eos. Trans. Amer. Geophys. Union (12), 1527-1540.

Chen, Y.T., Chen, Z.L. and Wang, B.Q., 1992, Seismological studies of earthquake prediction in China: A review. In: Dragoni, M. and Boschi, E. (eds.), Earthquake Prediction. Il Cigno Galileo Galilei, Roma, 71-109.

Chung, W.Y. and Kanamori, H., 1976, Source process and tectonic implications of the Spanish deep-focus earthquake of March 29, 1954, Phys. Earth Planet. Interi. 13, 85-96.

Deng, Q., Xu, X. and Yu, G., 1994, Characteristics of regionalization of active faults in China and their genesis. In: Department of Science and Technology, State Seismological Bureau of China (ed.), Active Fault Research in China 1-14. (in Chinese)

Ding, G.Y. (ed.), 1991, Lithospheric Dynamics of China. Explanatory Notes for the Atlas of Lithospheric Dynamics of China, Seismological Press, Beijing, 600 pp. (in Chinese)

Ding, G.Y., 1996, The research on active fault in China, J. Earthq. Pred. Res. 5, 317-325. (in Chinese)

Fan, C.J. and Chen, Y.K., 1992, Crustal structure of western Yunnan. In: Kan, R. J. (ed.), Geophysical Studies of Yunnan Province, Yunnan University Press, Kunming, 102-109. (in Chinese)

Fitch, T.J., 1975, Compressional velocity in source regions of deep earthquakes: An application of the master event technique, Earth Planet. Sci. Lett. 26, 156-166.

Fukao, Y., 1972, Source process for a large earthquake and its tectonic implications - the western Brazil earthquake of 1963, Phys. Earth Planet. Interi. 5, 61-76.

Got, J.-L., Frechet, J. and Klein, F.W., 1994, Deep fault plane geometry inferred from multiplet relocation beneath the south flank of Kilauea, J. Geophys. Res. 99, 15375-15386.

Gu, G.X. (ed.), 1983, Catalogue of Chinese Earthquakes, 1 and 2, Science Press, Beijing, 1,228 pp. (in Chinese)

Guo, S.M., Zhang, J., Li, X.G., Xiang, H.F., Chen, T.N. and Zhang, G.W., 1984, Fault displacement and recurrence intervals of earthquakes at the northern segment of Honghe fault zone, Seismology and Geology 6, 1-12. (in Chinese with English abstract)

Jiang, K. (ed.), 1993, The 1988 Lancang-Gengma Earthquakes $(M=$ 7.6, 7.2) in Yunnan, China, Yunnan University Press, Kunming, 387 pp. (in Chinese)

Kan, R.J., Zhang, S.C., Yan, F.T. and Yu, L.S., 1977, Present tectonic stress and its relation to the characteristics of recent tectonic activity in southwestern China, Acta Geophysica Sinica 20(2), 96-109. (in Chinese with English abstract)

Kan, R.J. and Lin, Z.Y., 1986, A preliminary study on crustal and upper mantle structures in Yunnan, Earthq. Res. China 2(4), 50 61. (in Chinese)

Li, P. and Wang, L.M., 1975, Discussion on the seismo-geological characteristics of the Yunnan-west Sichuan region, Scientia Geologica Sinica (4), 308-325. (in Chinese with English abstract)

Li, P. (ed.), 1993, The Xianshuihe-Xiaojiang Fault Zone, Seismological Press, Beijing, 267 pp. (in Chinese)

Liu, J.H., Liu, F.T., Wu, H., Li, Q. and Hu, G., 1989, Three-dimension velocity image of the crust and upper mantle beneath North-South Zone in China, Acta Geophysica Sinica 32(2), 152-161.

Ma, X.Y. (ed.), 1987, Explanatory Notes of the Lithosphireic Dynamics Map of China and Adjacent Seas, Scale 1: 4000000, Geological Publishing House, Beijing. (in Chinese)
Ma, X.Y. (ed.), 1989, Lithospheric Dynamics Atlas of China, China Cartographic Publishing House, Beijing, 68pp. (in Chinese)

Ma, Z.J. and Xue, F., 1983, Depth distribution and a preliminary discussion on the "seismic layer" in the Chinese continent, Research in Seismological Science 3(3), 43-46. (in Chinese)

Min, Z.Q. (ed.), 1995, Catalogue of Chinese Historical Strong Earthquakes, Seismological Press, Beijing, 514pp. (in Chinese)

Molnar, P. and Tapponnier, P., 1975, Cenozoic tectonics of Asia: Effects of a continental collision, Science 159(4201), 419-426.

Mozaffari, P., Wu, Z.L. and Chen, Y.T., 1998, Rupture process of November 6, 1988, Lancang-Gengma, Yunnan, China, earthquake of $M_{\mathrm{S}}=7.6$ using empirical Green's function deconvolution method, Acta Seismologica Sinica 11(1), 1-12.

Pacheco, J.F., Scholz, C.H. and Sykes, L.R., 1992, Changes in frequency-size relationship from small to large earthquakes, $\mathrm{Na}$ ture 355, 71-73.

Qin, C., Papazachos, C. and Papadimitriou, E., 2002, Velocity field for crustal deformation in China derived from seismic moment tensor summation of earthquakes, Tectonophysics 359(1/2), 2946.

Scholz, C.H., 1982, Scaling laws for large earthquakes: Consequences for physical models, Bull. Seism. Soc. Amer. 72(6), 1-14.

Scholz, C.H., 1990, The Mechanics of Earthquakes and Faulting, Cambridge University Press, Cambridge, 439pp.

Seismological Bureau of Sichuan Province (ed.), 1979, The 1976 Songpan Earthquake, Seimological Press, Beijing, 112pp. (in Chinese)

Su, Y.J. and Qin, J.Z., 2001, Strong earthquake activity and relation to regional neo-tectonic movement in Sichuan-Yunnan Region, Earthq. Res. China 17(1), 24-34. (in Chinese with English abstract)

Sun, R.M. and Liu, F.T., 1991, Seismic tomography of Sichuan, Acta Geophysica Sinica 34(6), 708-716.

Teng, C.T., Chang, Y.M. and Hsu, K.L., 1979, Tectonic stress field in China and its relation to plate movement, Phys. Earth Planet. Interi. 18, 257-273.

Waldhauser, F. and Ellsworth, W.L., 2000, A double difference earthquake location algorithm: Method and application to the Northern Hayward Fault, California, Bull. Seism. Soc. Amer. 90(6), 1353 1368.

Waldhauser, F., 2001, HypoDD: A Computer Program to Compute Double-difference Earthquake Location, U. S. Geol. Surv. Openfile report, 01-113, Menlo Park, California.

Wang, C.Y., Mooney, W.D., Wang, X.L.,Wu, J.P., Lou, H. and Wang, F., 2002, A study on 3-D velocity structure of upper mantle in Sichuan and Yunnan region, Acta Seismologica Sinica 15(1), 117.

Wang, C.Y., Wu, J.P., Lou, H., Zhou, M.D. and Bai, Z.M., 2003, $\mathrm{P}$-wave crustal velocity structure in western Sichuan and eastern Tibetan region, Science in China (Ser. D) 46(Suppl.), 254-265.

Wang, Q., Zhang, P.Z., Freymueller, J.T., Bilham, R., Larson, K. M., Lai, X.A., You, X.Z., Niu, Z.J., Wu, J.C., Li, Y. X., Liu, J.N., Yang, Z.Q. and Chen, Q.Z., 2001, Present-day crustal deformation in continental China constrained by Global Positioning System measurements, Science 249, 574-577.

Wang, S.Y., Wu, G. and Shi, Z.L., 1999, Catalogue of Chinese Current Earthquakes (1912-1990, $\left.M_{S} \geq 4.7\right)$, Chinese Science and Technology Press, Beijing, 637pp. (in Chinese)

Wen, X.Z., 1998, Assessment of time-dependent seismic hazard on segment of active fault, and its problem. Chinese Science Bulletin 43(23), 41-50. 
Western Yunnan Earthquake Prediction Experiment Site, Seismological Bureau of Yunnan Province, China (ed.), 1998, The $1996 \mathrm{Li}$ jiang Earthquake in Yunnan, China, Seismological Press, Beijing, 188 pp. (in Chinese)

Xie, Y.S. and Cai, M.B., 1983-1987, Compilation of Historical Materials of Chinese Earthquakes, 1 to 5, Science Press, Beijing, 4,471 pp. (in Chinese)

Xu, L.S., Chen, Y.T. and Fasthoff, S., 1998, Inversion for rupture process of the 1996 Lijiang, Yunnan, China $M_{\mathrm{S}} 7.0$ earthquake by empirical Green's function technique, In: Western Yunnan Earthquake Prediction Experiment Site, Seismological Bureau of Yunnan Province, China (ed.), The 1996 Lijiang Earthquake in Yunnan, China, Seismological Press, Beijing, pp. 79-81. (in Chinese)

Xu, X.W., Wen, X.Z., Zheng, R.Z., Ma, W.T., Song, F.M. and Yu, G.H., 2003, Pattern of latest tectonic motion and its dynamics for active blocks in Sichuan-Yunnan region, China, Science in China (Ser. D) 46(Suppl.), 210-226.

Xu, Z.H., Wang, S.Y., Huang, Y.R. and Gao, A.J., 1989, The tectonic stress field of Chinese continent deduced from a great number of earthquakes, Acta Geophysica Sinica 32(6), 636-647. (in Chinese with English abstract)

Yang, Z.X., Chen, Y.T. and Zhang, H.Z., 1999, Relocation of the Zhangbei-Shangyi earthquake sequence, Seismological and Geomagnetic Observation and Research 20,6-9. (in Chinese with English abstract)
Yang, Z.X., Chen, Y.T. and Zhang, H.Z., 2002, Relocation and seismogenic structure of the 1998 Zhangbei-Shangyi earthquake sequence, Acta Seismologica Sinica 15(4), 383-394.

Yang, Z.X., Yu, X.W., Zheng, Y.J., Chen, Y.T., Ni, X.X. and Chen, W., 2004, Earthquake relocation and 3-dimensional crustal structure of P-wave velocity in central-western China, Acta Seismologica Sinica 26(1), 19-29. (in Chinese with English abstract)

Zhang, G.M., Wang, S.Y., Li, L., Zhang, X.D. and Ma, H.S., 2002, Focal depth and its tectonic implications of the continental earthquakes in China, Chinese Science Bulletin 47(9), 663-668. (in Chinese with English abstract)

Zhao, Z., Fan, J., Zeng, S.H., Hasegawa, A. and Horiuchi, S., 1997, Crustal structure and accurate hypocenter determination along the Longmenshan fault zone, Acta Seismologica Sinica 19(6), 615622. (in Chinese with English abstract)

Zhao, Z. and Zhang, R.S., 1987, Primary study of crustal and upper mantle velocity structure of Sichuan Province, Acta Seismologica Sinica 9(2), 154-166. (in Chinese with English abstract)

Zhou, S.Y., Zhang, Y.G., Ding, G.Y., Wu, Y., Qin, X.J., Shi, S.Y., Wang, Q., Yiu, X.Z., Qiao, X.J., Shuai, P. and Deng, G.J., 1998, A preliminary research establishing the present-time intraplate blocks movement model on the Chinese mainland based on GPS data, Acta Seismologica Sinica 20(4), 347-355. (in Chinese with English abstract) 